\title{
Conceptual Design for the Pilot- Scale Plutonium Oxide Processing Unit in the Radiochemical Processing Laboratory
}
GJ Lumetta
$\mathrm{CH}$ Delegard
DE Meier MK Edwards
JM Tingey
SA Jones
AJ Casella
BM Rapko

August 2014

Pacific Northwest

NATIONAL LABORATORY

Proudly Operated by Battelle Since 1965 


\title{
DISCLAIMER
}

This report was prepared as an account of work sponsored by an agency of the United States Government. Neither the United States Government nor any agency thereof, nor Battelle Memorial Institute, nor any of their employees, makes any warranty, express or implied, or assumes any legal liability or responsibility for the accuracy, completeness, or usefulness of any information, apparatus, product, or process disclosed, or represents that its use would not infringe privately owned rights. Reference herein to any specific commercial product, process, or service by trade name, trademark, manufacturer, or otherwise does not necessarily constitute or imply its endorsement, recommendation, or favoring by the United States Government or any agency thereof, or Battelle Memorial Institute. The views and opinions of authors expressed herein do not necessarily state or reflect those of the United States Government or any agency thereof.

\author{
PACIFIC NORTHWEST NATIONAL LABORATORY \\ operated by \\ BATTELLE \\ for the \\ UNITED STATES DEPARTMENT OF ENERGY \\ under Contract DE-AC05-76RL01830
}

Printed in the United States of America
Available to DOE and DOE contractors from the Office of Scientific and Technical Information, P.O. Box 62, Oak Ridge, TN 37831-0062; ph: (865) 576-8401 fax: $(865) 576-5728$
email: reports $a$ adonis.osti.gov
Available to the public from the National Technical Information Service 5301 Shawnee Rd., Alexandria, VA 22312 ph: (800) 553-NTIS (6847) email: orders@ntis.gov <http://www.ntis.gov/about/form.aspx> Online ordering: http://www.ntis.gov




\title{
Conceptual Design for the Pilot- Scale Plutonium Oxide Processing Unit in the Radiochemical Processing Laboratory
}

\author{
GJ Lumetta \\ $\mathrm{CH}$ Delegard \\ DE Meier \\ MK Edwards \\ JM Tingey \\ SA Jones \\ AJ Casella \\ BM Rapko
}

August 2014

Prepared for

the U.S. Department of Energy

under Contract DE-AC05-76RL01830

Pacific Northwest National Laboratory

Richland, Washington 99352 



\begin{abstract}
This report describes a conceptual design for a pilot-scale capability to produce plutonium oxide for use as exercise and reference materials, and for use in identifying and validating nuclear forensics signatures associated with plutonium production. This capability is referred to as the Pilot-scale Plutonium oxide Processing Unit (P3U), and it will be located in the Radiochemical Processing Laboratory at the Pacific Northwest National Laboratory. The key unit operations are described, including plutonium dioxide $\left(\mathrm{PuO}_{2}\right)$ dissolution, purification of the $\mathrm{Pu}$ by ion exchange, precipitation, and conversion to oxide by calcination.
\end{abstract}





\section{Summary}

The National Technical Nuclear Forensics Center (NTNFC) has funded Pacific Northwest National Laboratory (PNNL) to establish a pilot-scale (up to $200 \mathrm{~g} \mathrm{Pu}$ per batch) capability to produce plutonium oxide for use as exercise and reference materials, and for use in identifying and validating nuclear forensics signatures associated with plutonium production. This capability is referred to as the Pilot-scale Plutonium oxide Processing Unit, abbreviated as "P3U." The P3U will be established in Room 604 in the Radiochemical Processing Laboratory (RPL).

The key unit operations for producing plutonium dioxide $\left(\mathrm{PuO}_{2}\right)$ are as follows. Plutonium will be received in the RPL in oxide form. The as-received oxide will be dissolved in nitric acid media. The resulting solution will be subjected to ion exchange to remove impurities from the $\mathrm{Pu}$ stream, and then the $\mathrm{Pu}$ will be precipitated in the form of a salt (e.g., oxalate, peroxide, hydroxide, or fluoride). This $\mathrm{Pu}$ salt will be converted back to $\mathrm{PuO}_{2}$ by heating (calcining). In order to make this capability a useful tool for identifying and validating nuclear forensics signatures, the system will be designed to be flexible, allowing variations in the different process parameters (e.g., temperature, manner of reagent addition, type of precipitating agent, etc.).

This report conceptually describes the P3U to be established at PNNL. The key features include

- Plutonium oxide will be received and placed in a glovebox in RPL/Room 604.

- The $\mathrm{PuO}_{2}$ will be dissolved in nitric acid media. Hydrofluoric acid will be added to aid in dissolution of the oxide.

- The dissolved Pu solution will be clarified by filtration and will then be purified by anion exchange using Reillex $\mathrm{HPQ}^{\circledR}$ anion exchange resin.

- Although the design allows for a variety of Pu precipitation steps, the conceptual design is based on $\mathrm{Pu}$ (III) oxalate precipitation. The purified $\mathrm{Pu}$ solution is adjusted to the +3 oxidation state with ascorbic acid, then is treated with oxalic acid to precipitate $\mathrm{Pu}_{2}\left(\mathrm{C}_{2} \mathrm{O}_{4}\right)_{3} \cdot 10 \mathrm{H}_{2} \mathrm{O}$.

- The $\mathrm{Pu}(\mathrm{III})$ oxalate will be calcined in a muffle furnace to convert it to $\mathrm{PuO}_{2}$.

- The $\mathrm{PuO}_{2}$ product will be packaged and distributed as directed by the NTNFC.

Functional descriptions are provided for each unit operation, and the various requirements for these operations are identified in this report. 



\section{Acknowledgments}

The authors thank the National Technical Nuclear Forensics Center for funding this work, and in particular, Bill Ulicny and Margaret Goldberg. The authors also thank the members of the Plutonium Expert Panel for all their helpful advice. The panel includes Leonard Gray, Alice Murray, Major Thompson, Donald Thorp, and Ted Venetz. 



\section{Acronyms and Abbreviations}

\begin{tabular}{|c|c|}
\hline${ }^{\circ} \mathrm{C}$ & degree(s) Celsius \\
\hline $\mathrm{Ci}$ & curie(s) \\
\hline $\mathrm{cm}$ & centimeter(s) \\
\hline DI & deionized \\
\hline DOE & U.S. Department of Energy \\
\hline DOT & U.S. Department of Transportation \\
\hline $\mathrm{ft}$ & foot/feet \\
\hline $\mathrm{g}$ & $\operatorname{gram}(\mathrm{s})$ \\
\hline GEA & gamma energy analysis \\
\hline $\mathrm{h}$ & hour(s) \\
\hline HDPE & high-density polyethylene \\
\hline $\mathrm{HF}$ & hydrofluoric acid \\
\hline $\mathrm{HNO}_{3}$ & nitric acid \\
\hline ID & inner diameter \\
\hline in. & $\operatorname{inch}(\mathrm{es})$ \\
\hline $\mathrm{kg}$ & kilogram(s) \\
\hline $\mathrm{L}$ & liter(s) \\
\hline M & molar (moles per liter) \\
\hline meq & milliequivalent(s) \\
\hline $\mathrm{mg}$ & milligram(s) \\
\hline $\mathrm{mL}$ & milliliter(s) \\
\hline mol & mole(s) \\
\hline NTNFC & National Technical Nuclear Forensics Center \\
\hline OD & outer diameter \\
\hline P3U & Pilot-scale Plutonium oxide Processing Unit \\
\hline PNNL & Pacific Northwest National Laboratory \\
\hline PP & polypropylene \\
\hline $\mathrm{Pu}$ & plutonium \\
\hline $\mathrm{PuO}_{2}$ & plutonium dioxide \\
\hline RPL & Radiochemical Processing Laboratory \\
\hline SRS & Savannah River Site \\
\hline vis/NIR & visible/near-infrared \\
\hline
\end{tabular}





\section{Contents}

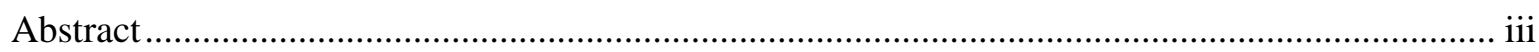

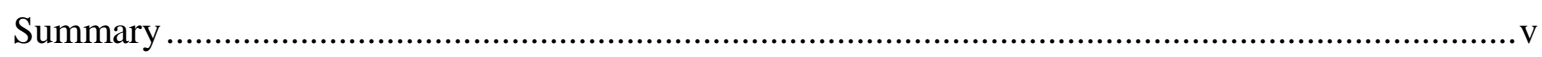

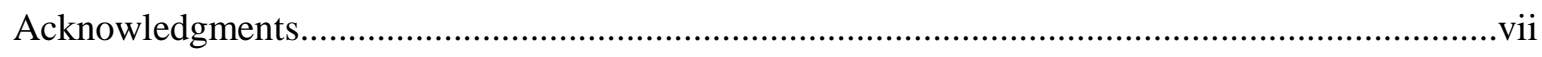

Acronyms and Abbreviations ........................................................................................ ix



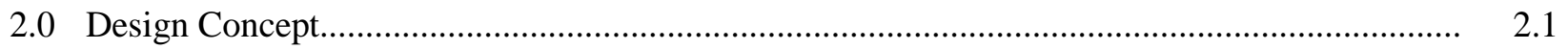

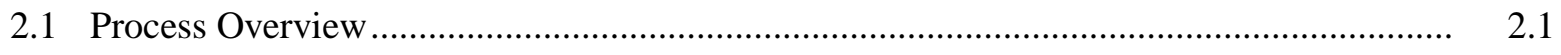

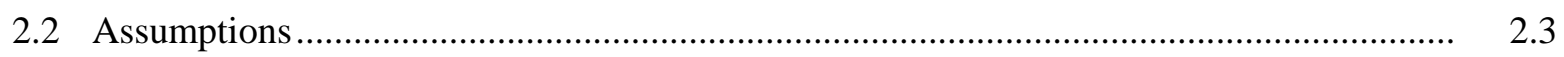

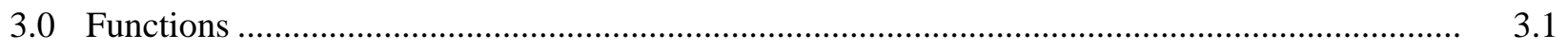

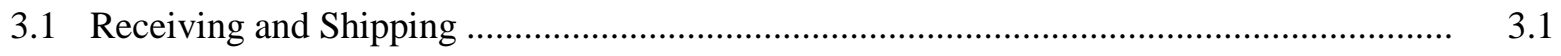

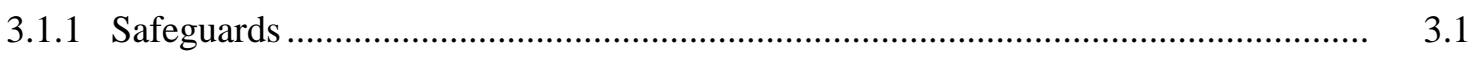

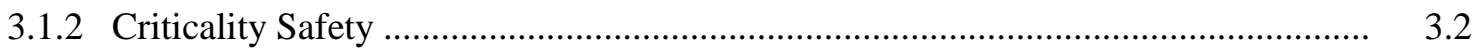

3.1.3 U.S. Department of Transportation Regulations ................................................. 3.2

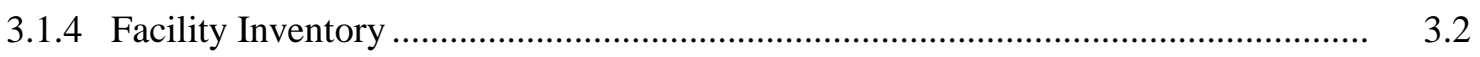

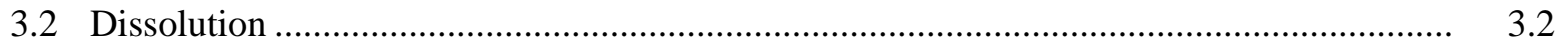

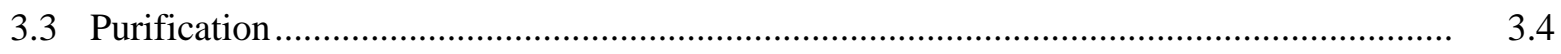

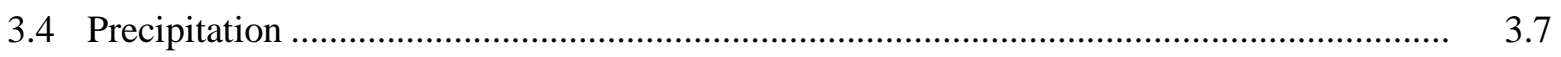

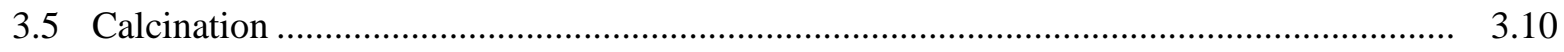

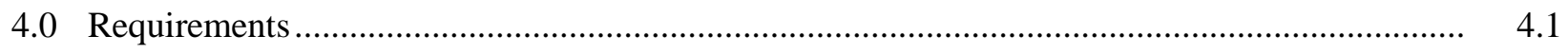

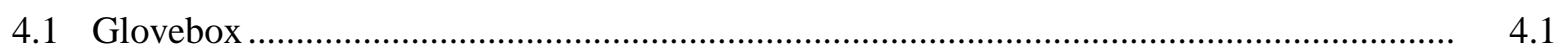



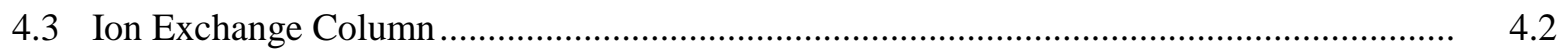

4.4 Precipitation Vessel and Filter ................................................................................. 4.3

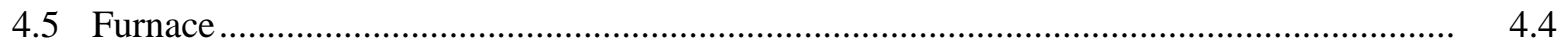

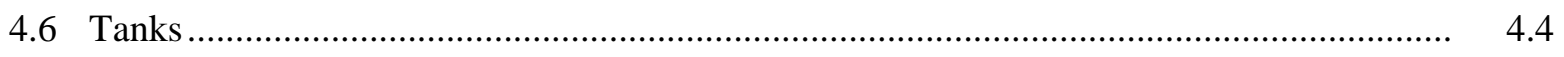

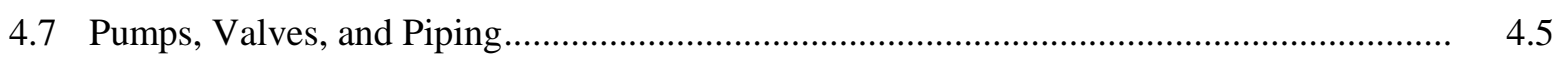

4.8 Product and Sample Containers …............................................................................ 4.5

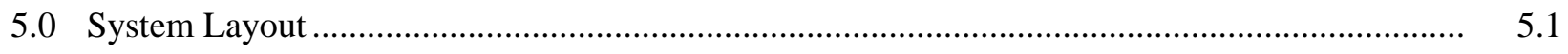

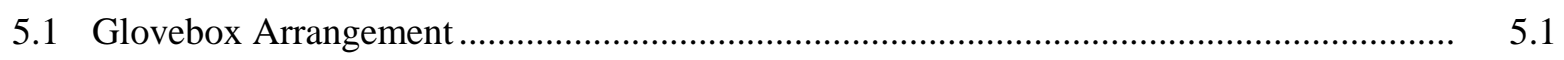

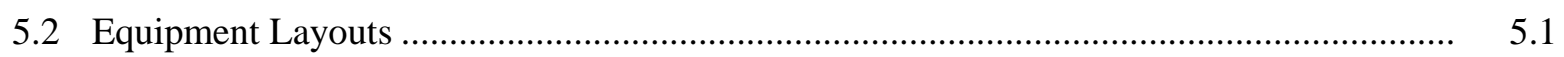

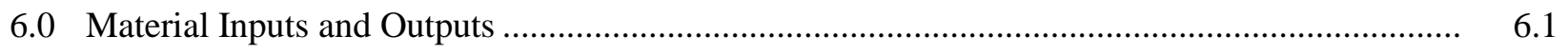

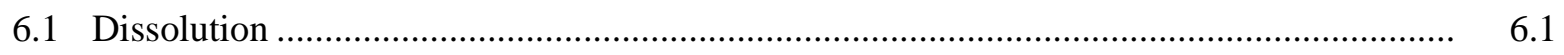

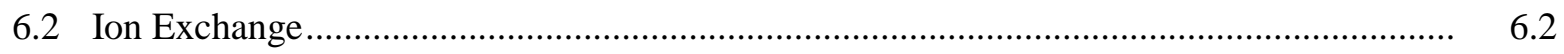

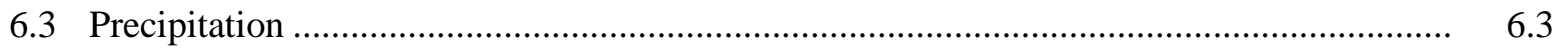

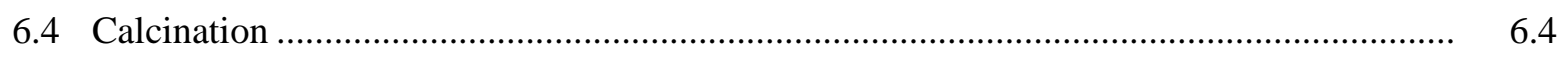






\section{Figures}

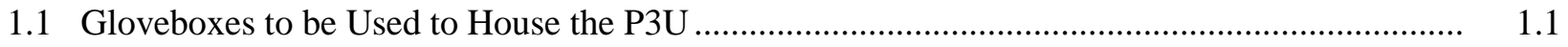

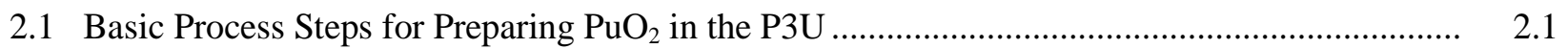

2.2 Schematic Representation of the $\mathrm{PuO}_{2}$ Dissolution and Anion Exchange Purification Steps ...... 2.2

2.3 Schematic Representation of the Pu Precipitation and Calcination Steps .................................. 2.3

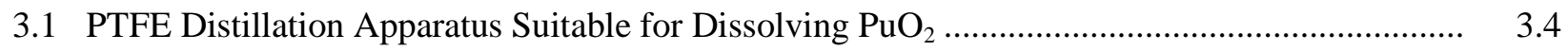

3.2 Location for Installation of On-Line Spectroscopic Tools ..................................................... 3.7

3.3 Diagram of Plutonium Oxalate Precipitation Apparatus ................................................... 3.10

3.4 Footprint of Available Space and Size Configurations for Muffle Furnaces and Tube

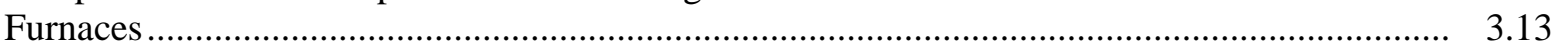

4.1 An Example Configuration for the $\mathrm{PuO}_{2}$ Sample Container ...................................................

5.1 Layout of RPL/Room 604. GB denotes glovebox. ............................................................ 5.1

5.2 Conceptual Layout of Equipment in Glovebox \#3 .......................................................... 5.3

5.3 Conceptual Layout of Equipment in Glovebox \#3 .................................................................. 5.3

6.1 Material Flows into and out of the Dissolver Section............................................................... 6.1

6.2 Material Flows into and out of the Ion Exchange Section ...................................................... 6.3

6.3 Material Flows into and out of the Precipitation and Calcination Sections ................................ 6.4

\section{Tables}

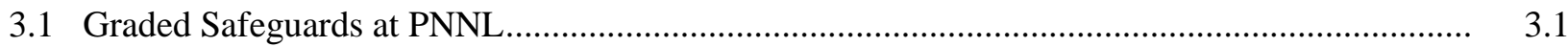

3.2 Maximum Impurity Concentrations for the Purified Pu Stream Based on the Hanford

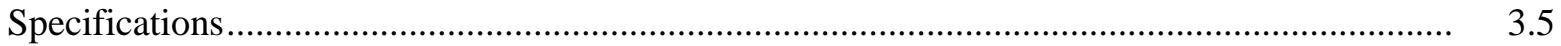

3.3 Commercially Available Muffle Furnaces Meeting the Requirements for Calcination .............. 3.12

3.4 Commercially Available Tube Furnaces Meeting the Requirements for Calcination ................. 3.12 


\subsection{Project Description}

Under the auspices of the National Technical Nuclear Forensics Center (NTNFC), Pacific Northwest National Laboratory (PNNL) is establishing a pilot-scale capability to produce plutonium oxide for use as exercise and reference materials, and for use in identifying and validating nuclear forensics signatures associated with plutonium production. In this context, "pilot-scale" is defined as up to $227 \mathrm{~g}$ plutonium dioxide $\left(\mathrm{PuO}_{2}\right)(200 \mathrm{~g} \mathrm{Pu})$ per batch produced. This capability is referred to as the Pilot-scale Plutonium oxide Processing Unit, abbreviated as "P3U." The P3U will be established in Room 604 in the Radiochemical Processing Laboratory (RPL) (Figure 1.1). The key unit operations will be dissolution of $\mathrm{PuO}_{2}$, purification of the $\mathrm{Pu}$ by ion exchange, precipitation, and conversion to oxide by calcination. In order to make this capability a useful tool for identifying and validating nuclear forensics signatures, the system will be designed to be flexible, allowing variations in the different process parameters (e.g., temperature, manner of reagent addition, type of precipitating agent, etc.).

To support the project, a comprehensive suite of analytical capabilities will be brought to bear on the $\mathrm{Pu}$ oxide production capability, including both inorganic and radiochemical analyses. A thorough analysis will also be performed on the feed and process materials in order to obtain the required baseline nuclear and chemical forensic signatures associated with $\mathrm{PuO}_{2}$ production flowsheets. State-of-the-art elemental and isotopic analytical support is available on-site, as are advanced microscopy (optical, scanning electron, and transmission electron), spectroscopy (e.g., micro ultraviolet-visible [UV-Vis], Raman, and atomic fluorescence, as well as solid UV-Vis, and Fourier transform infrared) and (X-ray) diffraction instruments needed to fully characterize the feed materials, the process streams, and the $\mathrm{PuO}_{2}$ product. Additionally, to improve the efficiency of operations, and to reduce personnel radiation exposure due to transferring samples out of the glovebox, installation of on-line instrumentation will be considered as part of the P3U design. Previous research at PNNL has shown that key process parameters, such as the Pu oxidation state and nitric acid $\left(\mathrm{HNO}_{3}\right)$ concentration, can be determined rapidly, and nondestructively, by using on-line spectroscopic monitoring tools. ${ }^{[1-3]}$

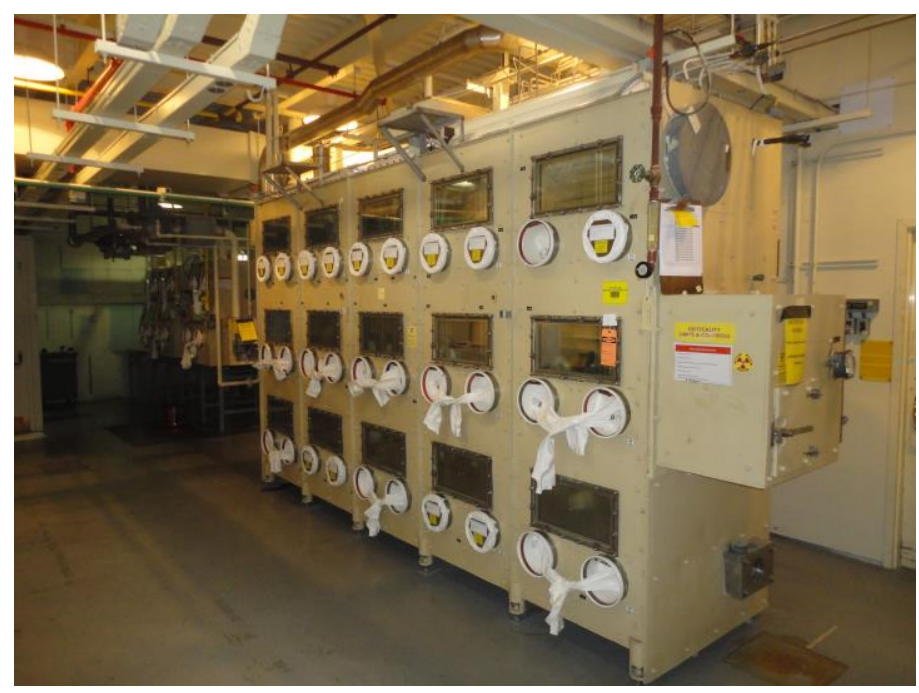

Figure 1.1. Gloveboxes to be Used to House the P3U 



\subsection{Design Concept}

\subsection{Process Overview}

The basic process for producing $\mathrm{PuO}_{2}$ is shown schematically in Figure 2.1. Plutonium will be received in the RPL in oxide form. The as-received oxide will be dissolved in $\mathrm{HNO}_{3}$ media. The resulting solution will be subjected to ion exchange to remove impurities from the $\mathrm{Pu}$ stream, and then the $\mathrm{Pu}$ will be precipitated in the form of a salt (e.g., oxalate, peroxide, hydroxide, or fluoride). This $\mathrm{Pu}$ salt will be converted to $\mathrm{PuO}_{2}$ by heating (calcining).



Figure 2.1. Basic Process Steps for Preparing $\mathrm{PuO}_{2}$ in the $\mathrm{P} 3 \mathrm{U}$

The feed to the process will be $\mathrm{PuO}_{2}$ shipped to PNNL from other U.S. Department of Energy (DOE) sites, such as the Savannah River Site (SRS) or Los Alamos National Laboratory (LANL). Quantities up to $1 \mathrm{~kg} \mathrm{Pu}$ as oxide may be received in a single shipment (in aliquots of $200 \mathrm{~g}$ Pu or less). Portions of the as-received $\mathrm{PuO}_{2}$ (containing approximately $200 \mathrm{~g} \mathrm{Pu}$ ) will be transferred into a glovebox in Room 604 of the RPL, where it will be dissolved in $\mathrm{HNO}_{3}$ and processed by ion exchange to remove impurities from the Pu solution. Figure 2.2 presents an overview of the dissolution and ion-exchange steps of the process. Nitric acid will be the primary medium for dissolving the as-received $\mathrm{PuO}_{2}$, but it is assumed that in most cases fluoride ion will need to be added to achieve adequate dissolution. Following dissolution, any undissolved material will be filtered from the Pu solution. The solution will be adjusted to approximately $7 \mathrm{M} \mathrm{HNO}_{3}$, and $30 \%$ hydrogen peroxide $\left(\mathrm{H}_{2} \mathrm{O}_{2}\right)$ will be added to adjust the Pu valence to the +4 oxidation state. ${ }^{[4-5]}$ If fluoride was added during the dissolution process, $\mathrm{Al}^{3+}$ will be added to complex the fluoride ion in solution. This adjusted feed will then be passed through an anion exchange column, where the anionic $\left[\mathrm{Pu}\left(\mathrm{NO}_{3}\right)_{6}\right]^{2-}$ species will be retained by the anion exchange material. ${ }^{[6]}$ The loaded column will be rinsed with $7 \mathrm{M} \mathrm{HNO}_{3}$ to remove impurities such as $\mathrm{Am}^{3+}$. Finally, the purified $\mathrm{Pu}$ will be eluted from the column using approximately 0.35 to $0.5 \mathrm{M} \mathrm{HNO}_{3}$. It should be noted that although anion exchange will generally be used for purifying the $\mathrm{Pu}$, the system will be designed to be flexible enough to consider other approaches, such as cation exchange. 




Figure 2.2. Schematic Representation of the $\mathrm{PuO}_{2}$ Dissolution and Anion Exchange Purification Steps

Following purification, the $\mathrm{Pu}$ will be precipitated from solution in the form of a salt, and then converted to the oxide by heating. Figure 2.3 schematically illustrates these steps in the process. The figure illustrates the steps for the $\mathrm{Pu}$ (III) oxalate precipitation process, but the system will be designed to accommodate various precipitation approaches. If needed, the Pu oxidation state in the feed to the precipitator will be adjusted. In the example illustrated, $\mathrm{Pu}$ is adjusted to the +3 oxidation state by adding a reductant such as ascorbic acid. The Pu solution is then mixed with the precipitating reagent (oxalic acid in the case illustrated) in either a direct-strike, reverse-strike, or simultaneous mode. The system will be designed to be flexible enough to handle these different precipitation scenarios. The precipitated solid will be collected by filtration and then fired to the oxide at a temperature in the range of 450 to $750^{\circ} \mathrm{C}$.

The $\mathrm{PuO}_{2}$ product will be sampled and characterized to determine product quality. At a minimum, this will include determining elemental purity and radiochemical purity. As directed by the client, samples of the product material will shipped for further analysis, both within PNNL and to other laboratories participating in the NTNFC program. A portion of the $\mathrm{PuO}_{2}$ product will be archived, and then the remainder will be redissolved to serve as feed to the next processing batch. 


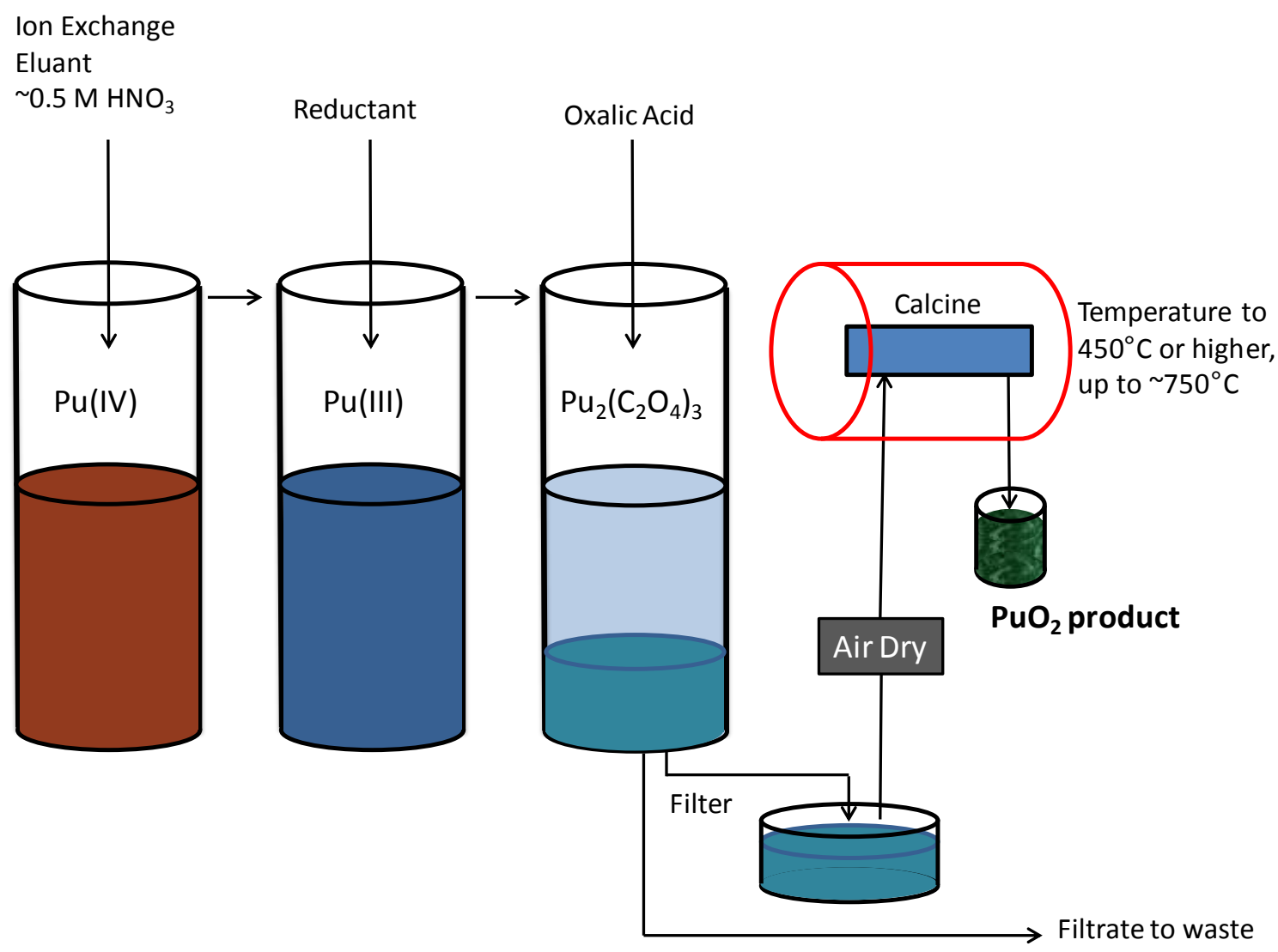

Figure 2.3. Schematic Representation of the Pu Precipitation and Calcination Steps

\subsection{Assumptions}

The following assumptions are made regarding the design and installation of the P3U.

1. The P3U will be established in existing gloveboxes in Room 604 of the RPL.

2. Up to $1 \mathrm{~kg}$ of $\mathrm{Pu}\left(\right.$ as $\left.\mathrm{PuO}_{2}\right)$ may be received in a given shipment, with the batch being separated into $\leq 200$ g aliquots.

3. The as-received $\mathrm{PuO}_{2}$ will have been previously processed to meet the 3013 canister requirements.

4. Dissolution and ion exchange will be performed on 200-g lots of Pu.

5. The feed to the ion exchange column will contain nominally $40 \mathrm{~g} \mathrm{Pu} / \mathrm{L}$ and $7 \mathrm{~mol} / \mathrm{L} \mathrm{HNO}_{3}$.

6. The feed to the precipitator will be adjusted to $\geq 30 \mathrm{~g} \mathrm{Pu} / \mathrm{L}$, depending on the specific test objectives.

7. Individual batches may be subdivided into several smaller, manageable amounts for the precipitation step.

8. The dissolver will require heating capability.

9. The ion exchange column will require heating and cooling capability.

10. The precipitator will require heating capability. 
11. Calcining will be a batch unit operation.

12. Any $\mathrm{PuO}_{2}$ product material that is not shipped out for analysis or archived will be recycled to the dissolver and processed as part of the subsequent batch. 


\subsection{Functions}

\subsection{Receiving and Shipping}

Successful production of pedigreed plutonium oxide in the P3U depends upon receiving plutonium stock materials in the RPL and shipping samples of these plutonium oxides to other laboratories across the DOE complex. Plutonium stock materials may include plutonium oxide or plutonium metal. The current baseline for planning purposes is the receipt of plutonium oxides in batches containing less than $200 \mathrm{~g}$ of plutonium. Multiple batches of similar material will be received so that nominally a $1 \mathrm{~kg}$ inventory of plutonium as plutonium oxide will be maintained at PNNL for this project.

Samples of the pedigreed plutonium oxide product will be shipped to other laboratories under the direction of NTNFC. The amounts of material in samples will be gram quantities and samples will be packaged in single-use stainless steel containers. The containers will be packaged in approved U.S. Department of Transportation (DOT) shipping containers and shipped after approval is obtained from NTNFC and the destination laboratory.

\subsubsection{Safeguards}

The RPL is capable of handling Category III levels of special nuclear material, but most of the inventory is maintained at Category IV levels. The limits for Category III levels are listed in Table 3.1. There is no lower limit for Category IV levels, and the value of the upper limit is equivalent to the lower limit of Category III inventories. All operations anticipated for the P3U can be performed at Category IV levels since the largest processing batch will be less than $200 \mathrm{~g}$ of plutonium.

Table 3.1. Graded Safeguards at PNNL (PNL-MA-500) ${ }^{1}$

\begin{tabular}{llcc}
\hline & \multicolumn{1}{c}{ Description of Material } & \multicolumn{2}{c}{ Pu Category III Limits $(\mathrm{kg})$} \\
\cline { 3 - 4 } Item & \multicolumn{1}{c}{ Lower $(\geq)$} & Upper $(<)$ \\
\hline Pure Products & $\begin{array}{l}\text { Pits, major components, button ingots, recastable metal, } \\
\text { directly converted materials }\end{array}$ & 0.2 & 0.4 \\
$\begin{array}{l}\text { High-Grade } \\
\text { Materials }\end{array}$ & $\begin{array}{l}\text { Carbides, oxides, nitrates, solutions }(\geq 25 \mathrm{~g} / \mathrm{L}) \text {, fuel } \\
\text { elements and assemblies, alloys and mixtures }\end{array}$ & 0.4 & 2 \\
$\begin{array}{l}\text { Low-Grade } \\
\text { Materials }\end{array}$ & $\begin{array}{l}\text { Solutions }(1-25 \mathrm{~g} / \mathrm{L}) \text {, process residues requiring } \\
\text { extensive reprocessing, }{ }^{238} \mathrm{Pu} \text { (except waste) }\end{array}$ & 3 & 16 \\
\hline
\end{tabular}

All plutonium stock materials received for the P3U will be maintained in a Material Balance Area according to the guidance provided by the Safeguards and Security Program documents in PNL-MA-500. Transfers of samples of pedigreed plutonium oxide to other laboratories will be done in compliance with the PNNL Safeguards and Security Program. If plutonium metal is received at PNNL in quantities greater than Category IV limits (200 g), increased accounting and control of plutonium inventories will be implemented to meet PNNL Safeguards and Security requirements.

\footnotetext{
${ }^{1}$ Nuclear Material Control and Accountability Plan. PNL-MA-500, Pacific Northwest National Laboratory, Richland, WA,
} 


\subsubsection{Criticality Safety}

Criticality prevention requirements dictate application of the double contingency principle, which requires that preventative measures be in place so that at least two unlikely, independent, and concurrent changes in process conditions must occur before criticality is possible. Criticality Safety Specifications (CSSs) identify limits on mass or number; moderation; reflection; spacing between batches, arrays, controlled areas, open shipping containers, or other accumulations of fissile material; and sometimes on volume or geometry and/or interaction. A CSS will be prepared for receiving, storage, handling, and shipping plutonium-bearing material as part of the P3U operations.

\subsubsection{U.S. Department of Transportation Regulations}

Plutonium-bearing materials will be shipped in DOT-certified containers according to DOT Regulations. PNNL has the capability to handle several certified containers including the 9977 drum. Trained shipping personnel at PNNL will prepare shipping documentation and label shipping containers.

Plutonium can be shipped in an arrangement of nested food-pack cans within a 9977 drum. This will be the primary method for shipping samples to other DOE sites. The certification of the 9977 drum does not expire until September 30, 2017. A 9977 drum is currently available at PNNL for this project. Dependent upon the number of samples shipped to different laboratories from a single batch of plutonium oxide, additional 9977 drums may need to be procured.

\subsubsection{Facility Inventory}

A Radioactive Material Evaluation Program has been implemented in the RPL to inventory radioactive materials in the facility. The current limit for in-process radioactive material within the facility is $1350 \mathrm{Ci}$ of ${ }^{239} \mathrm{Pu}$ equivalents, which is over $20 \mathrm{~kg}$ of ${ }^{239} \mathrm{Pu}$. This inventory includes all the projects in the building, but current inventories in the building allow sufficient room for receiving up to $1 \mathrm{~kg}$ of plutonium as the oxide.

\subsection{Dissolution}

The function of the dissolution stage of the process is to convert the as-received $\mathrm{PuO}_{2}$ feed material into an aqueous $\mathrm{HNO}_{3}$ solution that is suitable for the ion-exchange purification step.

$\mathrm{PuO}_{2}$ can be dissolved slowly in boiling mineral acids. The most common method involves refluxing the oxide in concentrated $\mathrm{HNO}_{3}$ containing fluoride ion for an extended time. The following mechanism has been proposed for this reaction: ${ }^{[7]}$

$$
\mathrm{HNO}_{3}+\mathrm{HF}+\mathrm{PuO}_{2} \rightarrow \mathrm{PuF}_{\mathrm{x}} \rightarrow \mathrm{H}_{\mathrm{z}-4} \mathrm{Pu}\left(\mathrm{NO}_{3}\right)_{\mathrm{Z}} \rightarrow \mathrm{Pu}\left(\mathrm{NO}_{3}\right)_{6}{ }^{2-}
$$

Dissolution by this method is initially rapid but slows as the reaction progresses. The rate is controlled by a chemical reaction at the $\mathrm{PuO}_{2}$ surface and is first order with respect to the $\mathrm{PuO}_{2}$ surface area and the concentration of the free hydrofluoric acid (HF) in solution. ${ }^{[8]}$ Dissolution rates with varying HF concentrations have been studied, and it was found that the dissolution rate increases with increasing HF concentration up to $0.2 \mathrm{M}$ and then decreases at higher concentrations. ${ }^{[9]}$ At HF concentrations above 
$0.2 \mathrm{M}$, insoluble plutonium fluoride $\left(\mathrm{PuF}_{4}\right)$ is precipitated and the dissolution rate decreases. In an effort to boost the dissolution rates, different oxidants in combination with HF have been explored. While some of the oxidants performed well, none was adequate to produce a dissolution rate faster than that obtained with $15.6 \mathrm{M} \mathrm{HNO}_{3} / 0.2 \mathrm{M} \mathrm{HF}$.

Nitric and hydrofluoric acid addition methods have been evaluated to determine an optimal dissolution strategy. ${ }^{[10]}$ The preferred method consisted of adding $\mathrm{HNO}_{3}$ and half the required amount of the $\mathrm{HF}$, heating the mixture at $110^{\circ} \mathrm{C}$ for $2 \mathrm{~h}$, then adding the remaining required amount of $\mathrm{HF}$. By proceeding in this manner, the dissolution efficiency improved to $95 \%$ after only two passes. To avoid the hazards associated with handling aqueous $\mathrm{HF}$, calcium fluoride $\left(\mathrm{CaF}_{2}\right)$ will be used in the P3U as the source of fluoride for the dissolution step.

The dissolution of $\mathrm{PuO}_{2}$ will be accomplished by the following general method. The $\mathrm{PuO}_{2}$ feed is placed in a polytetrafluoroethylene (PTFE, e.g., Teflon ${ }^{\circledR}$ ) distillation apparatus similar to the one depicted in Figure 3.1. The vessel is constructed of PTFE to minimize introduction of impurities into the Pu solution. For a 227-g batch of $\mathrm{PuO}_{2}(200 \mathrm{~g} \mathrm{Pu})$, a two-strike dissolution process is assumed. ${ }^{\text {(a) }}$ Each strike uses $1 \mathrm{~L}$ of $15.7 \mathrm{M} \mathrm{HNO}_{3}$ containing $0.1 \mathrm{M} \mathrm{CaF}_{2}$ (giving a total fluoride concentration of $0.2 \mathrm{M}$ ). A typical dissolution procedure would be as follows. First, $1 \mathrm{~L}$ of $15.7 \mathrm{M} \mathrm{HNO}_{3}$ and $7.8 \mathrm{~g}(0.1 \mathrm{~mole})$ of $\mathrm{CaF}_{2}$ is added to the vessel containing the $\mathrm{PuO}_{2}$ feed material. The distillation apparatus is sealed, placed in either a heating block or heating mantle, and digested at $110^{\circ} \mathrm{C}$ for $2 \mathrm{~h}$ with mechanical stirring. After $2 \mathrm{~h}$, an additional $7.8 \mathrm{~g}(0.1$ mole $)$ of $\mathrm{CaF}_{2}$ is added to bring the total $\mathrm{F}^{-}$concentration to approximately $0.2 \mathrm{M}$ and the solution is digested at $110^{\circ} \mathrm{C}$ for an additional $2 \mathrm{~h}$ with mechanical stirring. Typical dissolution efficiencies after the first-pass dissolution are assumed to be between 70 and $90 \%$. At this point, the $\mathrm{Pu}$ solution is removed, leaving the undissolved $\mathrm{PuO}_{2}$ heels in the reaction chamber for a second pass through the dissolution process. The second dissolution strike is identical to the first. A twopass dissolution will result in $2 \mathrm{~L}$ of $13.2 \mathrm{M} \mathrm{HNO}_{3} / 0.2 \mathrm{M} \mathrm{F}^{-} / 0.1 \mathrm{M} \mathrm{Ca}^{2+} / 0.4 \mathrm{M} \mathrm{H}_{2}\left[\mathrm{Pu}\left(\mathrm{NO}_{3}\right)_{6}\right]$ (neglecting any complexation of Pu by fluoride ion).

At any point in the process, samples can be removed through a sample port to assess $\mathrm{Pu}$ solution concentrations, perform residue analysis, etc. Furthermore, metal coupons could be introduced into the dissolution vessel for metal corrosion testing if required by the client.

(a) Multiple smaller-volume strikes could also be used if this were found to be more effective. 


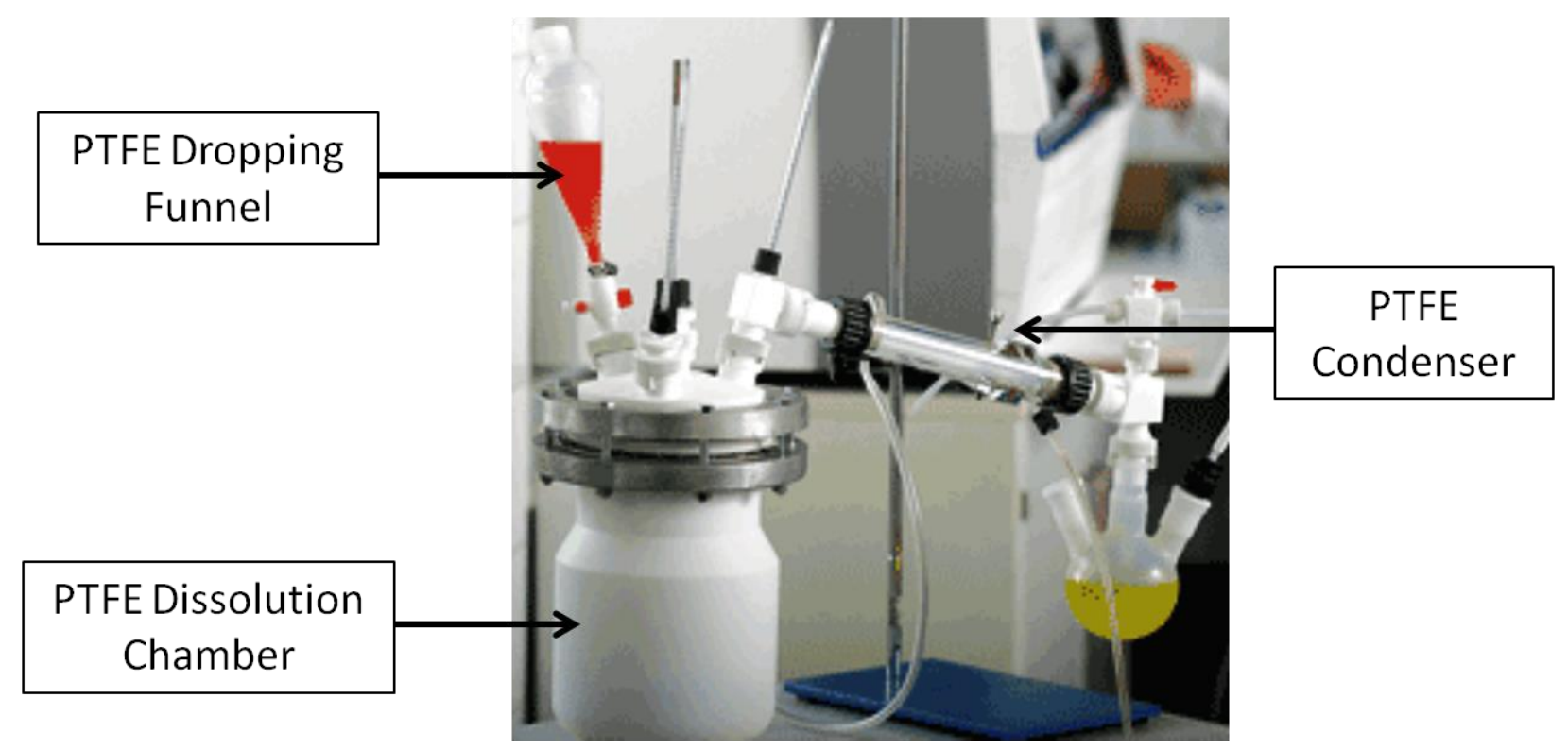

Figure 3.1. PTFE Distillation Apparatus Suitable for Dissolving $\mathrm{PuO}_{2}$

Solution Clarification: Before introduction to the ion exchange column, any undissolved solids must be removed from the dissolved Pu solution. Commercial off-the-shelf filtration units will be used for this purpose. The filtration equipment will be made of plastic (e.g., polypropylene [PP] or high-density polyethylene [HDPE]) or ceramic to minimize metal-ion contamination of the dissolved Pu solution. After filtration, the clarified Pu nitrate solution will be transferred to a tank and adjusted for the purification step as described in the next section.

\subsection{Purification}

The function of the purification step is to remove impurities from the dissolved $\mathrm{Pu}$ stream. The primary impurities of concern are the ingrown daughter products (e.g., $\left.{ }^{241} \mathrm{Am}\right)$, but depending on the processing history of the feed $\mathrm{PuO}_{2}$, other impurities might be present as well. The specifications for the purified $\mathrm{Pu}$ stream will be defined by the specific needs of the NTNFC signature development program. For the purpose of this conceptual design report, the specifications given in Table 3.2 will be adopted. These specifications are based on those for the feed to the Hanford oxalate precipitation process. ${ }^{[1]}$

Various well-established methods are available for purifying $\mathrm{Pu}$ in $\mathrm{HNO}_{3}$ solutions. These methods include precipitation, solvent extraction, and ion exchange. Anion exchange is the method of choice for this project, but the system will be designed with sufficient flexibility that cation exchange or extraction chromatography methods could be considered in the future. Anion exchange has been shown to be very effective for Pu purification, and indeed is the method selected at SRS for both Pu and Np purification in the HB-Line, Phase II. ${ }^{[12-14]}$ 
Table 3.2. Maximum Impurity Concentrations for the Purified Pu Stream Based on the Hanford Specifications $^{[11]}$

\begin{tabular}{lclc}
\hline & $\begin{array}{c}\text { Maximum Concentration in } \\
\text { Ion Exchange Product, } \\
\mu \mathrm{g} / \mathrm{mL}\end{array}$ & & $\begin{array}{c}\text { Maximum Concentration in } \\
\text { Impurity }\end{array}$ \\
\hline $\mathrm{Ag}$ & 100 & $\mathrm{Mo}$ & $\begin{array}{c}\text { Exchange Product, } \\
\mu \mathrm{g} / \mathrm{mL}\end{array}$ \\
$\mathrm{Al}$ & 1,500 & $\mathrm{Ni}$ & 100 \\
$\mathrm{~B}$ & 100 & $\mathrm{P}$ & 500 \\
$\mathrm{Be}$ & 100 & $\mathrm{~Pb}$ & 400 \\
$\mathrm{Bi}$ & $\mathrm{Si}$ & 100 \\
$\mathrm{Cr}$ & 200 & $\mathrm{Sn}$ & 500 \\
$\mathrm{Cu}$ & 1,500 & $\mathrm{Ti}$ & 100 \\
$\mathrm{Fe}$ & 100 & $\mathrm{Zr}$ & 500 \\
$\mathrm{Mn}$ & 2,000 & $\mathrm{Ca}+\mathrm{K}+\mathrm{Li}+\mathrm{Mg}+\mathrm{Na}$ & 500 \\
\hline
\end{tabular}

The following approach will be taken to purify the Pu solution by anion exchange. The $\mathrm{HNO}_{3}$ concentration of the $\mathrm{Pu}$ feed solution will be adjusted to approximately $7 \mathrm{M} \mathrm{HNO}_{3}$. The nitrous acid typically present in such relatively concentrated $\mathrm{HNO}_{3}$ solutions serves to adjust the $\mathrm{Pu}$ oxidation state to the desired +4 , but $\mathrm{H}_{2} \mathrm{O}_{2}$ will be added as required to achieve complete conversion to $\mathrm{Pu}(\mathrm{IV})$. At this high nitrate concentration, tetravalent $\mathrm{Pu}$ has been shown to sorb strongly onto strongly basic anion-exchange resins as the hexanitrate dianion $\left[\mathrm{Pu}\left(\mathrm{NO}_{3}\right)_{6}\right]^{2-}{ }^{26]}$ The anion exchange resin will be contained in a jacketed column made from quartz. The jacketed column will allow for processing at non-ambient temperatures. The circulating fluid for the jacketed column will be heated or cooled using a circulating bath. The circulating-bath reservoir will likely by housed outside of the glovebox, with self-contained lines running the heat transfer fluid to and from the jacketed column. The use of quartz as the column material will provide relatively good radiation resistance and the transparency of quartz allows for ready viewing of the resin. Viewing of the resin will be important to observe whether the resin bed remains properly packed and check that no channeling occurs, which would alter the ability of the resin to selectivity load and so purify $\mathrm{Pu}$. The column will contain screens at either end to prevent resin particles from leaving the column. These screens will be adjustable to fit various amounts of resin as needed, and will be designed to accommodate potential shrinking and swelling of the resin. A column diameter of 3 in. is proposed. The 3 in. diameter will provide a safe geometry to help mitigate criticality concerns but still will provide sufficient column capacity to readily achieve the target loading of 0.84 moles of $\mathrm{Pu}$.

For the initial stages of this project, the proposed resin for this system is Reillex $\mathrm{HPQ}^{\circledR}$, now sold by Vertellus Specialties. Reillex HPQ is a macroporous, strongly basic anion-exchange resin containing mostly ( 70\%) methylated poly(4-vinylpyridine) cross-linked with di-vinylbenzene. ${ }^{[15]}$ This resin has been used for decades at both SRS and at LANL for Pu purification. ${ }^{[16]}$ The superior chemical and radiation stability of this material over other strongly basic, commercial anion-exchange resins makes it the material of choice for actinide separations in high radiation environments.

Prior to loading the Pu-containing feed solution, the resin will be converted from the as-received chloride form to the nitrate form by washing with excess $1 \mathrm{M} \mathrm{NaNO}_{3}$, contacting with $8 \mathrm{M} \mathrm{HNO}_{3}$ at $85^{\circ} \mathrm{C}$ for 45 minutes, and then rinsing with deionized (DI) water. ${ }^{[12]}$ The hot $\mathrm{HNO}_{3}$ treatment has been shown 
to prevent an otherwise exothermic event observed for the as-received resin in contact with $8 \mathrm{M} \mathrm{HNO}_{3}$, and also improves the kinetic properties of the resin. ${ }^{[17]}$

Based on the dissolution process described in Section 3.2, it is assumed that the ion-exchange feed solution will be adjusted to $7 \mathrm{M} \mathrm{HNO}_{3}$ using $3.4 \mathrm{M} \mathrm{HNO}_{3}$. Assuming $\mathrm{CaF}_{2}$ was added to aid in dissolving the $\mathrm{PuO}_{2}$, aluminum nitrate will also be added to complex the fluoride ion present in the ion-exchange feed solution. Hydrogen peroxide will be used to adjust the Pu valence to the +4 oxidation state. ${ }^{[4-5]}$ The adjusted feed solution will be pumped through the column, with the effluent collected in an appropriate receiving tank. The resin will then be rinsed with six bed volumes of $7 \mathrm{M} \mathrm{HNO}_{3}$. This rinsing solution will also be directed to the receiving tank containing the effluent. The column-loaded $\mathrm{Pu}$ will then be eluted with low concentration (ca. $0.35 \mathrm{M}$ ) $\mathrm{HNO}_{3}$ solution. ${ }^{[12,18]}$ This Pu-containing eluate will be captured in a receiving tank for storage and delivery to the precipitation area of the glovebox.

Data from Sigma-Aldrich Co. indicates that the capacity of Reillex HPQ is 3.4 meq/g dry weight and that the as-received resin is $55 \%$ water, thus giving an as-received capacity of $1.53 \mathrm{meq} / \mathrm{g}$ as-received resin. This information indicates that approximately $1,110 \mathrm{~g}$ of resin would be required to process $200 \mathrm{~g}$ of $\mathrm{Pu}$. The bulk density has been reported as $0.89 \mathrm{~g} / \mathrm{mL},{ }^{[16]}$ which indicates that at least $1,240 \mathrm{~mL}$ of bed

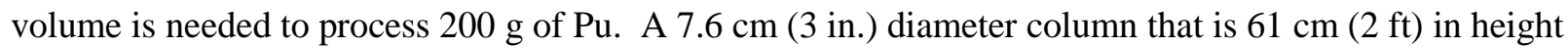
has a calculated volume of $2.78 \mathrm{~L}$, or more than twice the volume needed for the resin bed. This allows for the possibility of other resins with somewhat lower exchange capacity to also be examined with the designed system.

It is highly desirable to equip the ion-exchange and associated equipment with spectroscopic tools for real-time monitoring of solution conditions. Visible/near-infrared (vis/NIR) spectrophotometry and Raman spectroscopy should be installed to monitor key attributes of the adjusted ion-exchange feed solution. Specifically, the vis/NIR can be used to verify that the Pu oxidation state is +4 , and the Raman spectrometer can be used to verify that the $\mathrm{HNO}_{3}$ concentration is $7 \mathrm{~mol} / \mathrm{L}$ before the solution is fed to the ion exchange column. Figure 3.2 illustrates the location where such measurements can take place. Both of these techniques can be performed remotely with in-line cells or probes being coupled by fiber optic cables to the spectrometers located outside the glovebox. ${ }^{[1]}$ These spectroscopic tools will be inserted between the ion exchange feed tank and the ion exchange column. The system can be valved such that the solution can flow through the spectroscopy equipment and back into the feed tank during the feed adjustment steps. Once the $\mathrm{Pu}$ oxidation state and $\mathrm{HNO}_{3}$ concentrations have been verified, the solution can be routed to the ion exchange column. The outlet of the ion exchange column can also be equipped with in-line vis/NIR (Figure 3.2). At this point, the column eluent can be monitored for Pu content so that only those fractions containing significant $\mathrm{Pu}$ are collected into the $\mathrm{Pu}$ product receipt tank. 


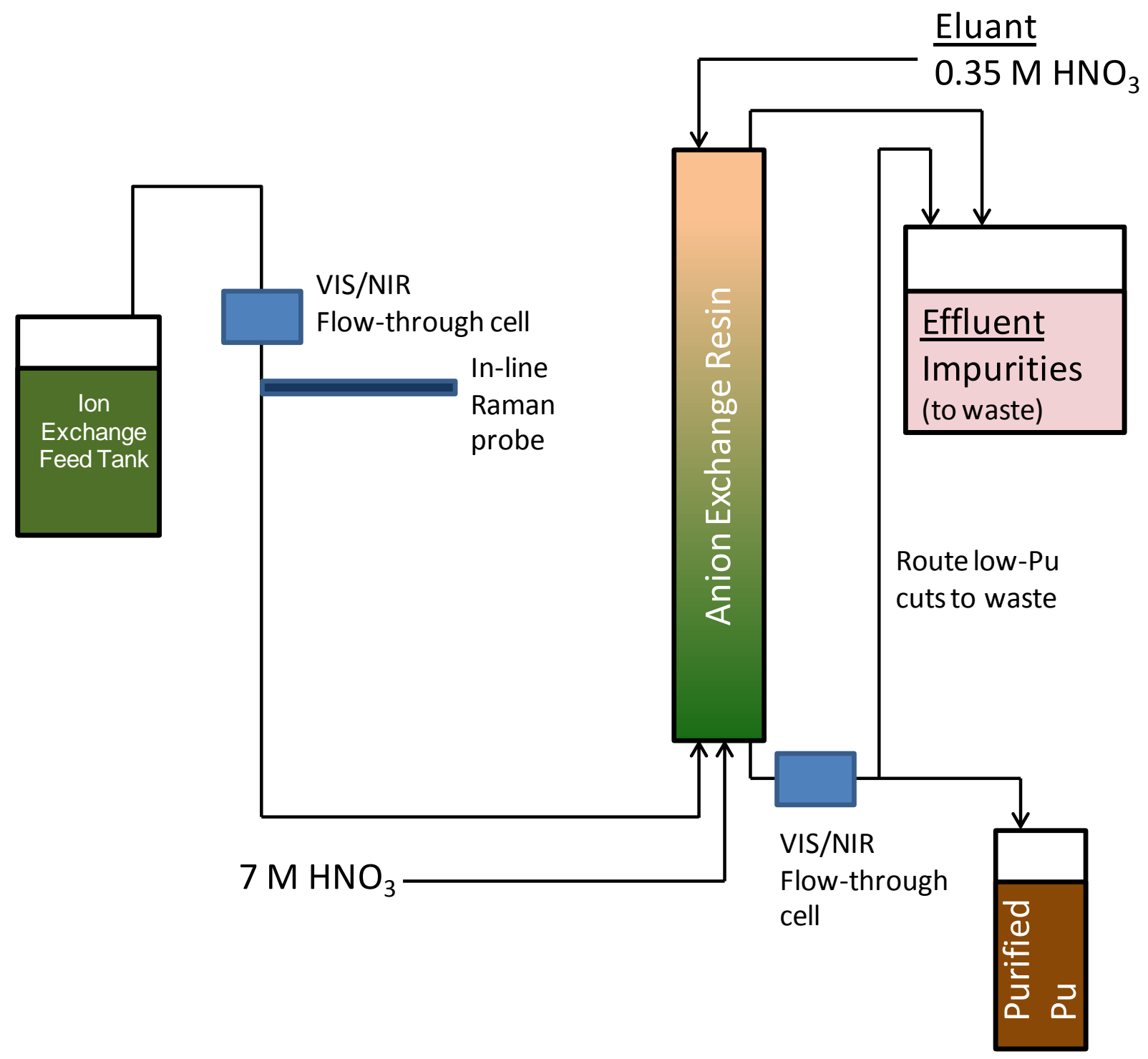

Figure 3.2. Location for Installation of On-Line Spectroscopic Tools

The system will contain pressure relief valves in each area that might be isolated in the process to mitigate the consequences of any violent gas release that might occur as the result of an exothermic or gas-releasing decomposition either from the nitrate solution or from resin decomposition. Fluid transfers with this system are controlled with pumps placed in-line with each system tank. This design gives the system the flexibility to pump feed, column wash, or eluate solutions in either an upstream or a downstream fashion. Loading the resin with solution in one column direction and stripping using a solution flowing in the opposite direction can be used to minimize the strip solution volume, and so is a desirable feature in this design.

\subsection{Precipitation}

The $\mathrm{Pu}(\mathrm{III})$ oxalate precipitation step functions to convert the $\mathrm{Pu}(\mathrm{IV})$ nitrate solution product from the anion-exchange purification step to a washed and damp $\mathrm{Pu}(\mathrm{III})$ oxalate product, by valence and acid 
adjustment and by chemical precipitation. Plutonium(III) oxalate has the formula $\mathrm{Pu}_{2}\left(\mathrm{C}_{2} \mathrm{O}_{4}\right)_{3} \cdot 10 \mathrm{H}_{2} \mathrm{O}$. The precipitation process may follow the chemical conditions given in an existing RPL procedure ${ }^{(\mathrm{a})}$ based on SRS experience ${ }^{[19]}$ but other conditions may be used as outlined in a review of $\mathrm{Pu}(\mathrm{III})$ oxalate precipitation chemistry. ${ }^{[20]}$ The optimum batch conditions for more concentrated $\mathrm{Pu}$ feed solutions involve slowly adding $1 \mathrm{M} \mathrm{H}_{2} \mathrm{C}_{2} \mathrm{O}_{4}$ (oxalic acid) solution (in direct strike fashion) to the $\mathrm{Pu}$ (III) solution at room temperature with a target slurry solution composition of $1 \mathrm{M} \mathrm{HNO}_{3}$ with $0.25 \mathrm{M}$ excess $\mathrm{H}_{2} \mathrm{C}_{2} \mathrm{O}_{4}{ }^{[20]}$ The NTNFC Plutonium Experts Panel has recommended that the precipitation system be designed to accommodate $\mathrm{Pu}$ concentrations in the range 10 to $30 \mathrm{~g} \mathrm{Pu} / \mathrm{L}$.

The precipitation reactor will be designed so that it can function either in a batch mode or in a continuous mode in which the $\mathrm{H}_{2} \mathrm{C}_{2} \mathrm{O}_{4}$ and $\mathrm{Pu}$ solutions are added simultaneously to the reactor vessel. The apparatus will be designed also to accommodate potential future $\mathrm{Pu}(\mathrm{IV})$ oxalate $\left[\mathrm{Pu}\left(\mathrm{C}_{2} \mathrm{O}_{4}\right)_{2} \cdot 6 \mathrm{H}_{2} \mathrm{O}\right]$ and other potential $\mathrm{Pu}$ precipitation schemes. Although $\mathrm{Pu}$ throughput is unlimited in the continuous mode, the batch size will depend on the Pu solution concentration and the maximum target production of $200 \mathrm{~g}$ of contained $\mathrm{Pu}$. In practice, the $200 \mathrm{~g} \mathrm{Pu}$ production may occur in two or three precipitation batches.

To prepare $\mathrm{Pu}(\mathrm{III})$ oxalate from $\mathrm{Pu}(\mathrm{IV})$ nitrate solution, the following sub-steps must be completed:

1. Adjust $\sim 80 \mathrm{~g} \mathrm{Pu}(\mathrm{IV}) / \mathrm{L}$ anion exchange eluate in $\sim 0.35 \mathrm{M} \mathrm{HNO}_{3}$ to the target $\mathrm{Pu}$ and $\mathrm{HNO}_{3}$ concentrations by dilution. Achieving target acid concentrations ordinarily will be reached using concentrated $(\sim 15.7 \mathrm{M}$ ) or dilute (no less than $0.2 \mathrm{M}) \mathrm{HNO}_{3}$.

2. Adjust the $\mathrm{Pu}$ valence to the +3 state. Both a chemical reductant (e.g., ascorbic acid, hydroxylamine) and a nitrous acid $\left(\mathrm{HNO}_{2}\right)$ scavenger (e.g., hydrazine $\left(\mathrm{N}_{2} \mathrm{H}_{4}\right)$, sulfamic acid, urea) are needed to prepare and stabilize the $\mathrm{Pu}(\mathrm{III})$ nitrate from the $\mathrm{Pu}(\mathrm{IV})$ feed solution. In the absence of a $\mathrm{HNO}_{2}$ scavenger, $\mathrm{Pu}(\mathrm{III})$ reoxidizes to $\mathrm{Pu}(\mathrm{IV})$.

3. Adjust the precipitation temperature. Ordinarily, precipitation will be conducted at ambient temperature $\left(\sim 25^{\circ} \mathrm{C}\right)$. If higher temperatures are needed, the solution temperatures will be adjusted accordingly.

4. Precipitate $\mathrm{Pu}(\mathrm{III})$ oxalate: batch or continuous precipitation of $\mathrm{Pu}(\mathrm{III})$ oxalate will be performed by mixing the freshly prepared $\mathrm{Pu}$ (III) nitrate solution with the $\mathrm{H}_{2} \mathrm{C}_{2} \mathrm{O}_{4}$. The $\mathrm{H}_{2} \mathrm{C}_{2} \mathrm{O}_{4}$ may be introduced as its solution, which is effectively limited to $\leq 1 \mathrm{M}$, or as solid crystals of $\mathrm{H}_{2} \mathrm{C}_{2} \mathrm{O}_{4} \cdot 2 \mathrm{H}_{2} \mathrm{O}$. The precipitating mixtures will be stirred using an overhead stirrer at controlled stirrer speed, or by air sparging. If elevated digestion temperatures are needed, a heated circulating bath will be employed.

5. Digest $\mathrm{Pu}(\mathrm{III})$ oxalate: the appropriate digestion/residence time will be monitored before the solution and the $\mathrm{Pu}(\mathrm{III})$ oxalate solids are separated.

6. Separate and wash $\mathrm{Pu}(\mathrm{III})$ oxalate: the $\mathrm{Pu}(\mathrm{III})$ oxalate solids will be filtered from the slurry, and the filter cake will be washed on the filter using a $\sim 0.5 \mathrm{M} \mathrm{HNO}_{3} / 0.2 \mathrm{M}$ $\mathrm{H}_{2} \mathrm{C}_{2} \mathrm{O}_{4}$ solution. Alternatively, the solids may be separated from the mother solution and washed by several settle/decant steps.

(a) Ryan, J. L. Purification of Plutonium Using Lewatit UMP-950 Ion Exchange Resin; Procedure 325-PU-Purify1; Pacific Northwest National Laboratory: Richland, WA, 1998. 
7. Deliver damp Pu(III) oxalate: the washed damp Pu(III) oxalate solids will be delivered to the next functional step in the process, drying and calcination.

For maximum flexibility, the precipitation vessel to be used in the testing will be based on the mixedsuspension, mixed-product-removal designs used in the Hanford Site Plutonium Finishing Plant Remote Mechanical A (RMA) and Remote Mechanical C (RMC) Lines, the Plutonium-Uranium Extraction Plant $\mathrm{N} \mathrm{Cell} \mathrm{Pu}(\mathrm{IV})$ oxalate continuous process vessels, and the test vessel used to develop $\mathrm{Pu}(\mathrm{IV})$ oxalate process parameters in the 1980s. ${ }^{[21]}$ The vessel will be designed to operate either in continuous mode with oxalic acid added as an aqueous solution, or in batch mode with the oxalic acid added as a solid or an aqueous solution. When operated in batch mode, the vessel must be able to accommodate $10 \mathrm{~L}$ of $\mathrm{Pu}$ (III) feed solution at $30 \mathrm{~g} / \mathrm{L}$; an additional $2 \mathrm{~L}$ of headspace is also assumed.

The vessel and all wetted surfaces will be constructed of PP or other plastic (e.g., polyetherether ketone, PEEK) with equivalent or better thermal (i.e., up to $80^{\circ} \mathrm{C}$ ), chemical $\left(\mathrm{HNO}_{3}\right)$, and radiological (alpha) resistance. Glass or metal will not be used and halocarbon plastics [e.g., PTFE, polyvinylidene fluoride] used only minimally because of the contamination residues they produce by corrosion/decomposition. If corrosion effects and corrosion products are to be investigated, coupons of the test materials may be introduced into the vessel.

Figure 3.3 illustrates the conceptual design of the precipitator. To be consistent with Hanford Site continuous processing practice, the precipitation vessel will be cylindrical with a rounded bottom that has a rounded cone rising from the center of the bottom. The vessel will be furnished with a central cylindrical draft tube and have a variable-speed overhead impeller running at the center bottom of the draft tube to provide a downward flow. Four vertical baffles placed around the outside of the draft tube wall will be used to improve mixing and solids suspension. The downward central flow and the rounded vessel bottom features also promote suspension of slurry solids. The baffles will be attached to the vessel lid. When operated in continuous mode, the metered $\mathrm{Pu}(\mathrm{III})$ nitrate and oxalic acid input solutions will be added to the draft tube just above the impeller so that intimate mixing occurs rapidly. When operated in batch mode, solid oxalic acid will be added through a funnel/tube arrangement in the lid to the precipitation vessel. The digestion temperature will be adjustable using a heating bath circulating through a jacket on the outside of the vessel. The product will be removed by suction through PP (or equivalent) tubing, and the slurry will be directed to a suction filter to separate the solids from the mother solution. With this arrangement, the solid filter cake may be washed on the filter pan. The damp filter cake then will be collected and sent to the next stage for drying and calcination. 

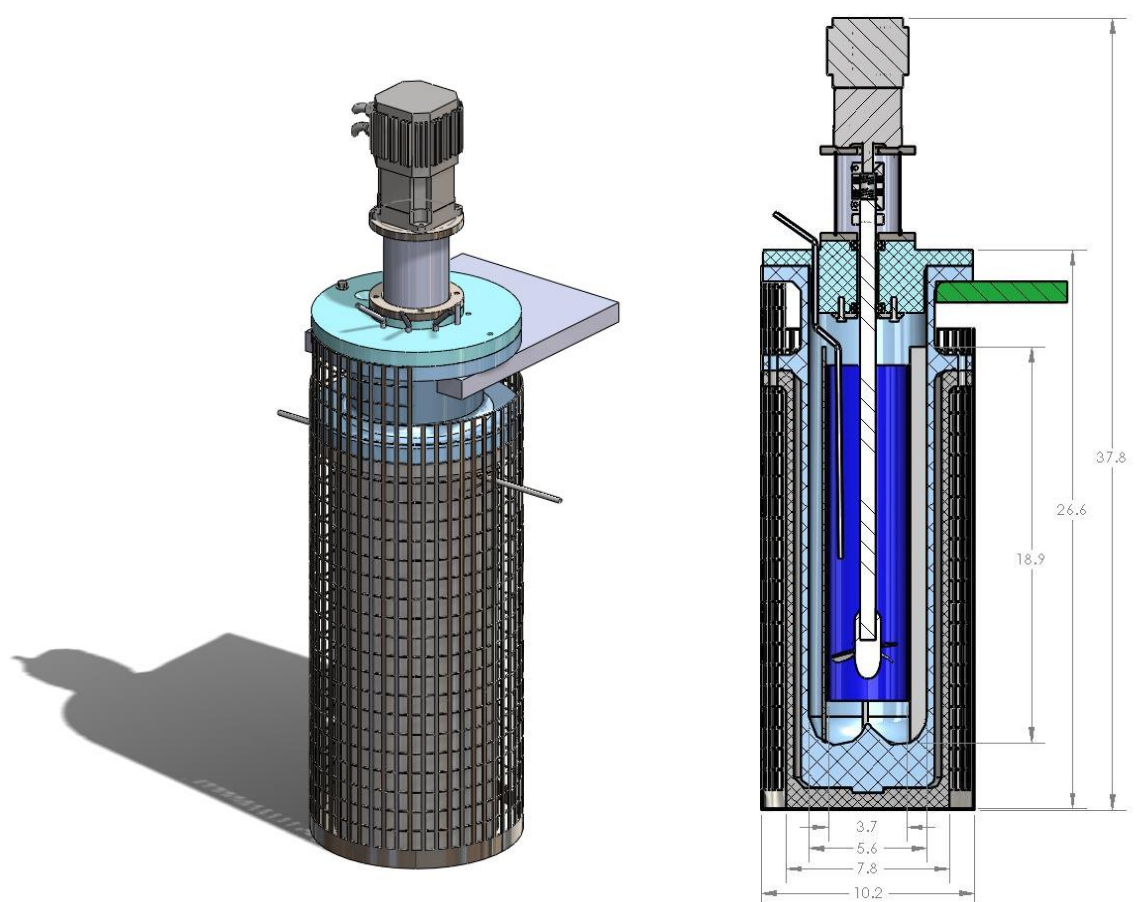

Figure 3.3. Diagram of Plutonium Oxalate Precipitation Apparatus

The same apparatus also can be used in the simpler batch precipitation mode. In batch mode, generally direct-strike introduction of the oxalic acid solution will be made to the Pu solution already present in the precipitation vessel. Reverse-strike addition (Pu solution added to oxalic acid solution) or addition of solid oxalic acid to the Pu solution also can be performed.

\subsection{Calcination}

In air, the thermal decomposition of both $\mathrm{Pu}(\mathrm{IV})$ and $\mathrm{Pu}$ (III) oxalate to $\mathrm{PuO}_{2}$ is mostly complete at $450^{\circ} \mathrm{C},{ }^{[22]}$ although higher temperatures, approximately $800^{\circ} \mathrm{C},{ }^{[19,23]}$ are often used to drive off residual carbon by air oxidation. The highest published temperature range used was $1200-1250^{\circ} \mathrm{C}$ for complete conversion to $\mathrm{PuO}_{2}{ }^{[22]}$ Calcination in argon requires higher temperatures for conversion, about $600{ }^{\circ} \mathrm{C}$, with carbon-containing impurities remaining due to lack of oxidation. To minimize carbon-containing impurities, $100 \% \mathrm{O}_{2}$ environments have been used. ${ }^{[22]}$

The prescribed standard method for conversion of $\mathrm{Pu}(\mathrm{III})$ oxalate by Porter and Symonds recommends heating $\mathrm{Pu}_{2}\left(\mathrm{C}_{2} \mathrm{O}_{4}\right)_{3} \cdot 10 \mathrm{H}_{2} \mathrm{O}$ in a stream of air from room temperature to $125^{\circ} \mathrm{C}$ at a rate of about $1.5^{\circ} \mathrm{C} / \mathrm{min}$ (over approximately $1 \mathrm{~h}$ ), and holding for $1 \mathrm{~h}$ at $125^{\circ} \mathrm{C}$ to convert to the anhydrous form $\mathrm{Pu}_{2}\left(\mathrm{C}_{2} \mathrm{O}_{4}\right)_{3}{ }^{\left[{ }^{[19]}\right.}$ After the $1 \mathrm{~h}$ holding period, the temperature is increased at a rate of $3-5^{\circ} \mathrm{C} / \mathrm{min}$ until the final calcination temperature is reached (most often between $450^{\circ} \mathrm{C}$ and $750^{\circ} \mathrm{C}$ ), which is maintained for 1 to $2 \mathrm{~h}$. The sample is then cooled to room temperature under the air stream. Samples can be taken and analyzed both before and after calcination to verify complete conversion to the oxide.

Although variations exist on the exact ramp rates, isotherms, and environments, there are common variables necessary for calcination of $\mathrm{Pu}$ (III) oxalate. The calcination furnace must have 1) a multiplestep programmable ramp rate for controlled heating, 2) it must be compatible for flowing environments of 
inert gas, air, and $\mathrm{O}_{2}$, and 3) it must be able to achieve a maximum temperature of $1,000^{\circ} \mathrm{C}$, although $1,200^{\circ} \mathrm{C}$ is more desirable. Additional considerations that must be made for installation in the Room 604 Glovebox \#1 are 1) voltage needed (e.g., 120 or $240 \mathrm{~V}$ ), as only $120 \mathrm{~V}$ is currently available; 2) size of the furnace (it must fit through the $14{ }^{15} / 16$ in. $(37.9 \mathrm{~cm}$ ) diameter bag-out port); 3) capacity to hold a batch of $200 \mathrm{~g} \mathrm{Pu}\left(386 \mathrm{~g} \mathrm{Pu}_{2}\left(\mathrm{C}_{2} \mathrm{O}_{4}\right)_{3} \cdot 10 \mathrm{H}_{2} \mathrm{O}\right)$; and 4) what crucibles should be used. Filtration should not be necessary on the exit gas lines from the furnace, especially if a baffle exists between the gas inlet and the top of the crucible.

The two standard furnace options are muffle and tube furnaces. In the case of the muffle furnace, within the size constraint to pass through the glovebox port, few options are available that meet all requirements (i.e., $1,200^{\circ} \mathrm{C}$ maximum temperature, controlled atmosphere, programmable temperature ramps, and appropriate size) without custom orders. The possibility exists to disassemble a furnace that may be slightly too large and pass the parts through the port. If multiple temperature ramps and holds are to be used, consideration should be given to modifying the furnace so that the control unit can be outside the glovebox, allowing remote operation of the furnace. This may also reduce the footprint needed.

Listed in Table 3.3 are the muffle furnaces that were identified that meet all of the above stated requirements. Option 1 will fit through the glovebox port with no modification; Options 2 and 3 would require disassembly by in-house crafts personnel prior to installation and reassembly afterwards. The advantage of Options 2 and 3 is an increased capacity for each calcination batch. It is advised not to fill the chamber more than two-thirds full to provide uniform heating and prevent damage to the furnace components. A $200 \mathrm{~g}$ batch of $\mathrm{Pu}$ would equate to approximately $380 \mathrm{~g}$ of Pu(III) oxalate decahydrate, which typically has a density of around 1 to $2 \mathrm{~g} / \mathrm{mL}$. As a conservative estimate, this would require $380 \mathrm{~mL}$ plus some headspace in the crucible. The crucibles will be constructed of $\mathrm{Pt}, \mathrm{Pt} / \mathrm{Rh}$, or Pt-plated stainless steel. These will likely be custom made.

Commercially available tube furnaces that meet the criteria listed above are limited to a maximum tube diameter of 2 in. $(5.1 \mathrm{~cm})$ due to the external size requirement for passing through the port on the glovebox. Within this limitation, the optimal configuration for the tube furnace is the split design, as it is more likely that it can be disassembled to fit through the port by removal of the upper hinged area. Capability for disassembly must be verified with the supplier for the chosen furnace prior to purchase. Table 3.4 lists two options for the split tube furnace that are commercially available; a custom-built tube furnace is also an option. In terms of crucible design, the largest capacity option would require a custombuilt boat and could only achieve $150 \mathrm{~mL}$ in the largest commercially available tube furnace. Based on the estimate of a $380 \mathrm{~mL}$ volume, even in the largest tube furnace option the sample may have to be split into three batches. Note: in the tube furnaces, there is a temperature differential along the length of the tube, and the entire length may not be usable if high uniformity is required.

Other considerations that will need to be taken into account during detailed design are 1) the possible need to line the inside of the furnace with stainless steel or Pt-plated stainless steel to prevent contamination of the $\mathrm{PuO}_{2}$ product by the furnace (e.g., from sloughing, etc.); 2) the bed of the $\mathrm{Pu}$ oxalate should not be greater than one-half inch deep, because otherwise incomplete calcination might result; and 3) capability to flow air or oxygen through the furnace during calcination is necessary. 
Table 3.3. Commercially Available Muffle Furnaces Meeting the Requirements for Calcination

\begin{tabular}{|c|c|c|c|c|c|c|c|c|}
\hline Option & $\begin{array}{l}\text { Furnace } \\
\text { Type }\end{array}$ & $\begin{array}{l}\text { Capacity } \\
\text { (in. }^{3} \text { ) }\end{array}$ & $\begin{array}{l}\text { Max } \\
\text { Temp. } \\
\left({ }^{\circ} \mathrm{C}\right)\end{array}$ & $\begin{array}{l}\text { Number } \\
\text { of Temp. } \\
\text { Ramps }\end{array}$ & $\begin{array}{c}\text { Chamber } \\
\text { Dimensions } \\
\quad(\text { in. }) \\
\mathrm{W} \times \mathrm{D} \times \mathrm{H}\end{array}$ & $\begin{array}{l}\text { Overall } \\
\text { Dimensions } \\
\quad(\text { in. }) \\
\mathrm{W} \times \mathrm{D} \times \mathrm{H}\end{array}$ & $\begin{array}{l}\text { Voltage } \\
\text { (VAC) }\end{array}$ & Vendor \\
\hline 1 & Muffle & 65 & 1200 & 30 & $4 \times 4 \times 4$ & $9 \times 8 \times 14$ & 110 & $\begin{array}{l}\text { MTI } \\
\text { Corporation }\end{array}$ \\
\hline 2 & Muffle & 120 & 1100 & 16 & $4 \times 8 \times 4$ & $15 \times 20 \times 17.5$ & 120 & Cole-Parmer \\
\hline 3 & Muffle & 120 & 1200 & 8 & $5 \times 6 \times 4$ & $11.3 \times 15.5 \times 18$ & 120 & Cole-Parmer \\
\hline Option & Model & & \multicolumn{3}{|l|}{ Website } & \multicolumn{3}{|l|}{ Notes } \\
\hline 1 & \multicolumn{2}{|c|}{ KSL-1100X-S } & \multicolumn{3}{|c|}{ www.mtixtl.com } & \multicolumn{3}{|c|}{ Meets all requirements } \\
\hline 2 & \multicolumn{2}{|c|}{$\begin{array}{l}\text { Lindberg Blue M } \\
\mathrm{T}-33852-30\end{array}$} & \multicolumn{3}{|c|}{ www.coleparmer.com } & \multicolumn{3}{|c|}{$\begin{array}{l}\text { Slightly too large for glovebox port; would } \\
\text { require disassembly prior to insertion. Can } \\
\text { be connected to a computer for } \\
\text { programming. }\end{array}$} \\
\hline 3 & \multicolumn{2}{|c|}{$\begin{array}{l}\text { Thermolyne } \\
\text { F47925-80 }\end{array}$} & \multicolumn{3}{|c|}{ www.coleparmer.com } & \multicolumn{3}{|c|}{$\begin{array}{l}\text { Slightly too large for glovebox port; would } \\
\text { require disassembly prior to insertion. } \\
\text { Injection port for purge gas adaptation. }\end{array}$} \\
\hline
\end{tabular}

Table 3.4. Commercially Available Tube Furnaces Meeting the Requirements for Calcination

\begin{tabular}{|c|c|c|c|c|c|c|c|c|}
\hline Option & $\begin{array}{l}\text { Furnace } \\
\text { Type }\end{array}$ & $\begin{array}{c}\text { Max } \\
\text { Temp } \\
\left({ }^{\circ} \mathrm{C}\right) \\
\end{array}$ & $\begin{array}{c}\text { Number of } \\
\text { Temp. } \\
\text { Ramps }\end{array}$ & $\begin{array}{l}\text { Tube } \\
\text { OD } \\
\text { (in.) }\end{array}$ & $\begin{array}{l}\text { Tube } \\
\text { ID } \\
\text { (in.) }\end{array}$ & $\begin{array}{c}\text { Heating } \\
\text { Zone } \\
\text { (in.) }\end{array}$ & $\begin{array}{c}\text { Overall } \\
\text { Dimensions } \\
\quad(\text { in. }) \\
\mathrm{W} \times \mathrm{D} \times \mathrm{H}\end{array}$ & $\begin{array}{l}\text { Voltage } \\
\text { (VAC) }\end{array}$ \\
\hline 4 & Split Tube & 1200 & 30 & 2 & 1.69 & 8 & $13.4 \times 11.8 \times 15.8$ & 110 \\
\hline 5 & Split Tube & 1200 & $\begin{array}{l}\text { multiple - } \\
\text { separate } \\
\text { connection } \\
\text { and purchase }\end{array}$ & 2 & 1.69 & 6 & $13 \times 10.5 \times 14$ & $\begin{array}{l}\text { separate } \\
\text { console } \\
(1140 \mathrm{~W})\end{array}$ \\
\hline Option & Vendo & & Model & \multicolumn{3}{|c|}{ Website } & \multicolumn{2}{|l|}{ Note } \\
\hline 4 & \multicolumn{2}{|c|}{ MTI Corporation } & OTF1200X-S & \multicolumn{3}{|c|}{ www.mtixtl.com } & \multicolumn{2}{|c|}{$\begin{array}{l}\text { Top must be removable to fit in } \\
\text { glovebox }\end{array}$} \\
\hline 5 & \multicolumn{2}{|c|}{ CM Furnaces Inc. } & $1000 \mathrm{k} 238-6$ & \multicolumn{3}{|c|}{ www.cmfurnaces.com } & \multicolumn{2}{|c|}{$\begin{array}{l}\text { Top must be removable to fit in } \\
\text { glovebox }\end{array}$} \\
\hline
\end{tabular}

The current usable footprint in Room 640 Glovebox \#1 is approximately 29 in. by 29 in. (73.7 cm by $73.7 \mathrm{~cm}$ ). Note: this footprint was measured from the outside of the box with approximation of wall thickness taken into account; exact dimensions may vary slightly. As shown in Figure 3.4, all five furnace options presented will have sufficient ventilation on all sides. Poor ventilation is unlikely to be an issue unless a larger furnace is needed, which would also require major disassembly of the furnace to install it through the bag-out port, with subsequent reassembly in the glovebox. 


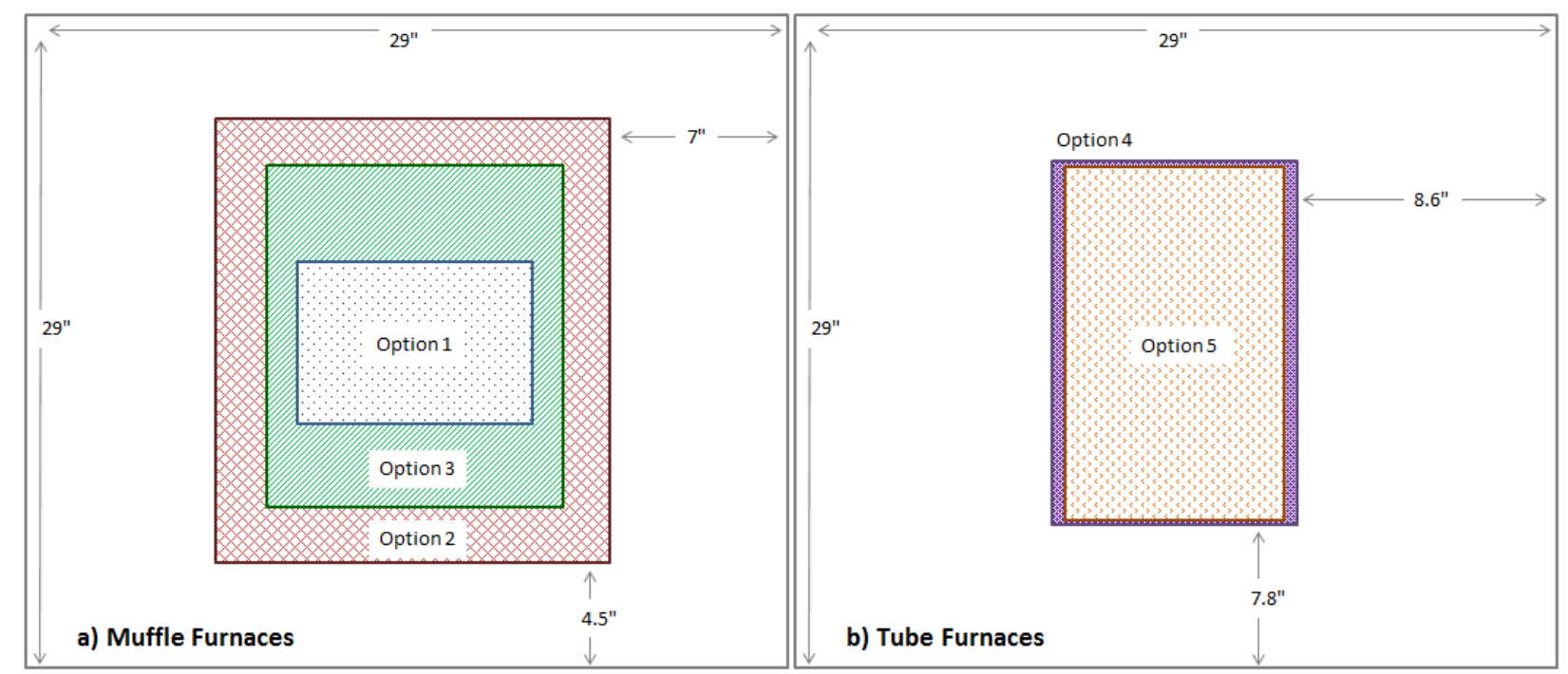

Figure 3.4 Footprint of Available Space and Size Configurations for a) Muffle Furnaces and b) Tube Furnaces

Modifications to the glovebox for calcination would require the insertion of a purge gas line and, if the furnace control is remote, electrical lines for the control unit. Ports 28 or 4 in Glovebox \#1 are available for this purpose. All of the furnaces listed are compatible with $120 \mathrm{~V}$ sources, which are already available in the glovebox. If a custom-built furnace is desired and requires $240 \mathrm{~V}$, additional power would need to be run to the glovebox. Additional items to be considered for the calcination step are tongs for crucible insertion/removal (for use in the muffle furnace), heat resistant gloves, and, if the tube furnace is used, additional tubes, a rod for proper placement into the tube, and possibly a shelf to maintain proper orientation of the boats. A stainless steel guard should be available to place over the top of the crucible to prevent contamination of the $\mathrm{PuO}_{2}$ product by material falling from the furnace.

If the conversion process were to be adapted to $\mathrm{Pu}(\mathrm{VI})$ oxalate or peroxide precipitation, the above furnaces would be suitable as they cover the required temperature range, can accommodate gas flow, and have the capability for various ramps and isotherms. ${ }^{[22-27]}$ For hydrofluorination conversion, logistic parameters of the above furnaces are sufficient, ${ }^{[24-25]}$ although additional consideration must be given to the compatibility of the furnace with anhydrous hydrogen fluoride as it corrodes ceramics and metals in the presence of water. Extra precautions of purging the system with dry inert gas, drying any unbound water off the sample prior to introduction of the anhydrous hydrogen fluoride, use of nickel crucibles, and encapsulation of the sample in nickel or platinum with connections to the purge gas may assist in compatibility. 



\subsection{Requirements}

This section describes the basic requirements needed for the P3U system in terms of facility and services, equipment, chemical reagents, test materials, and analytical services. Unless otherwise noted, the materials of construction for the various equipment items are to be determined. Vessel dimensions will be determined based on evaluation of nuclear criticality risk.

\subsection{Glovebox}

All of the unit operations require installation in a negative-pressure glovebox equipped with an airlock and bag-out ports. The glovebox(es) must be certified to handle up to $200 \mathrm{~g}$ of Pu as oxide. The following utilities to the gloveboxes are required:

- $120 \mathrm{~V}$ electrical service (multiple receptacles)

- vacuum

- compressed air

- gas lines (e.g., for air or oxygen)

- ports with tubing for introducing nonradioactive reagent solutions, water, and circulating temperature control loops

- port for data cables

\subsection{Dissolver}

\section{Equipment}

- a balance with a capacity of $400 \mathrm{~g}$ and a sensitivity of $0.01 \mathrm{mg}$ or better

- 1500-mL capacity PTFE dissolution vessel, equipped with a PTFE condenser and a port for solids addition

- heating equipment: heating block or heating mantle

- vacuum filtration apparatus with filter paper or PTFE filter membrane

- 3-L capacity tank for receipt of clarified Pu solution

$\underline{\text { Reagents }}$

- DI water

- reagent-grade concentrated $(\sim 16 \mathrm{M}) \mathrm{HNO}_{3}$

- reagent-grade $\mathrm{CaF}_{2}$ 


\section{$\underline{\text { Test Materials }}$}

- Pu oxide

- coupons for corrosion doping (e.g., 325L stainless steel, Hastelloy ${ }^{\circledR}$, Pyrex $^{\circledR}$, etc.) (if required for the experimental objectives)

\section{Analytical Services}

- Pu solution concentrations by absorption spectrophotometry or gamma energy analysis (GEA)

- Pu isotopic analysis by inductively coupled plasma mass spectrometry

- Pu residue analyses by X-ray diffraction and fusion digestion followed by alpha energy analysis (AEA).

\subsection{Ion Exchange Column}

\section{Equipment}

- metering pumps for solution transport

- flow meters for monitoring solution flow from and to the tanks and at the column entrance and exit

- one Raman spectrometer with two detectors for monitoring $\mathrm{HNO}_{3}$ concentrations at the column entrance and exit

- one vis/NIR spectrophotometer and two flow-through cells for Am and Pu monitoring at the column entrance and exit

- multiplexer for Raman and vis/NIR spectrometers

- one computer for analysis of spectroscopic and flow data

- 6-L capacity ion-exchange feed tank

- 15-L capacity ion-exchange effluent receipt tank, shielded to reduce worker exposure to the $59.5 \mathrm{keV}$ ${ }^{241}$ Am gamma emission

- 3.5-L capacity purified-Pu receipt tank

- three-way valves

- two-way valves

- variable-pressure relief valves

- 3 in. $(7.6 \mathrm{~cm})$ diameter, $2 \mathrm{ft}(61 \mathrm{~cm})$ high, jacketed quartz ion-exchange column, including variableheight screens

\section{Reagents}

- DI water

- high-purity concentrated (15.7 M) $\mathrm{HNO}_{3}$ 
- $30 \% \mathrm{H}_{2} \mathrm{O}_{2}$

- ion exchange resin (Reillex HPQ or alternative to be determined)

\section{$\underline{\text { Analytical Services }}$}

- Pu and Am solution concentrations by on-line spectrophotometry; supplemented by GEA and/or AEA

- nitric acid concentration by on-line Raman spectroscopy; supplemented by potentiometric titration with standard sodium hydroxide

- inductively coupled plasma optical emission spectrometry for metal analysis

\subsection{Precipitation Vessel and Filter}

\section{Equipment}

- 12-L capacity precipitation vessel, equipped with overhead mechanical stirrer and jacketed for temperature control

- circulating bath for temperature control

- filter pan, PP or equivalent construction; dimensions to be determined, but must accommodate a filter cake of approximately $400 \mathrm{~mL}$

- 7.5-L oxalate feed adjustment tank

- 12-L oxalate filtrate receipt tank

- two variable-rate metering pumps (maximum $1 \mathrm{~L} / \mathrm{h}$ )

- PP, or equivalent, tubing

\section{$\underline{\text { Reagents }}$}

- DI water

- reagent-grade ascorbic acid, crystal

- reagent-grade $85 \%$ hydrazine, solution

- high-purity concentrated $\sim 15.7 \mathrm{M} \mathrm{HNO}_{3}$, solution

- reagent-grade oxalic acid, crystal

\section{$\underline{\text { Test Materials }}$}

- coupons for corrosion doping (e.g., 316L stainless steel, Hastelloy, Pyrex, etc.)

- Pu nitrate eluate solution from ion-exchange purification 


\title{
$\underline{\text { Analytical Services }}$
}

- Pu solution concentrations by absorption spectrophotometry or GEA

- Pu valence by spectrophotometry

- $\mathrm{HNO}_{3}$ concentration by Raman spectroscopy; supplemented with titration in ammonium oxalate complexing buffer ${ }^{[28]}$

\subsection{Furnace}

\section{Equipment}

- balance for weighing sample before and after calcination. A balance with a sensitivity of $0.1 \mathrm{mg}$ is necessary; however, a balance with $0.01 \mathrm{mg}$ sensitivity is more desirable.

- furnace with a multiple-step programmable ramp rate for controlled heating that is compatible with flowing environments of inert gas, air, and $\mathrm{O}_{2}$, can achieve a maximum temperature of $1,000^{\circ} \mathrm{C}$, (although $1,200^{\circ} \mathrm{C}$ is more desirable), and will pass through the bag-out port

- Muffle furnace option:

$\mathrm{Pt}, \mathrm{Pt} / \mathrm{Rh}$, or Pt-plated crucibles, tongs. Optional: heat resistant gloves

- Tube furnace option:

\author{
$\mathrm{Pt}, \mathrm{Pt} / \mathrm{Rh}$, or Pt-plated boats \\ tubes \\ placement rod \\ optional: shelf for inside tube, heat resistant gloves
}

$\underline{\text { Chemicals }}$

- optional: compressed $\mathrm{O}_{2}$, compressed $\mathrm{Ar}$

\subsection{Tanks}

The tanks used must be resistant to attack by $\mathrm{HNO}_{3} / \mathrm{HF}$ solutions. The tentatively chosen materials of construction for the tanks are as follows:

- clarified-Pu solution tank: stainless steel

- ion-exchange feed solution tank: stainless steel

- ion-exchange effluent tank: stainless steel

- ion-exchange purified-Pu-solution tank: plastic (e.g., HDPE, PP, or PEEK) 
- oxalate feed adjustment tank: plastic (e.g., HDPE, PP, or PEEK)

- oxalate filtrate tank: stainless steel

All tanks will be installed in duplicate to provide redundancy and operational flexibility.

\subsection{Pumps, Valves, and Piping}

The internal components of all pumps, valves, and piping used must be resistant to attack by $\mathrm{HNO}_{3} / \mathrm{HF}$ solutions. For solutions in which downstream metal-ion contamination might be an issue, plastic materials such as HDPE might need to be used. It is assumed that metering pumps will be used throughout the P3U.

\subsection{Product and Sample Containers}

There are no special container requirements for the bulk product material since it will not be stored for an extended period. It is assumed that immediately after completion of a batch, aliquots of the bulk material will be distributed to other laboratories, and an archived sample will be taken. The remaining material is assumed to be recycled back to the dissolver and used for the next process run.

Sample containers will be constructed of stainless steel and will be compatible with the 9977 shipping drum. The containers will have a threaded lid for robust closure. Figure 4.1 illustrates one potential configuration for the sample container.



Figure 4.1. An Example Configuration for the $\mathrm{PuO}_{2}$ Sample Container 



\subsection{System Layout}

\subsection{Glovebox Arrangement}

RPL/Room 604 contains three gloveboxes. These are numbered 1 through 3, with Glovebox \#1 being located at the north end of the room and Glovebox \#3 at the south end (Figure 5.1). Conceptually, the plutonium oxide production capability in RPL/Room 604 will consist of five primary work stations. The dissolution station will be located at the south end of Glovebox \#3, immediately adjacent to the airlock door. This station will consist of a balance, the dissolution vessel, and a filtration apparatus. The ion exchange station will be located in the middle part of Glovebox \#3. This will consist of the ion-exchange feed vessel(s), the ion exchange column, the purified-Pu receipt vessel, and the effluent waste tank. At least two nonradioactive chemical feed tanks will also be included in the ion exchange system; these can be assumed to be located on the top of the glovebox. The plutonium precipitation station will be located at the north end of Glovebox \#3. This will consist of the precipitation vessel with mixer, a circulating heating bath (located outside the glovebox), and pumps for metering-in the Pu solution and the precipitant. Also associated with the precipitation station will be a filter apparatus for collecting the precipitated Pu. The calcination work station will be located in Glovebox \#1. This station will primarily consist of a muffle furnace. Finally, the product distribution work station will be located in Glovebox \#2. This work station will consist mainly of a balance for measuring out aliquots of the product for shipping and archiving.

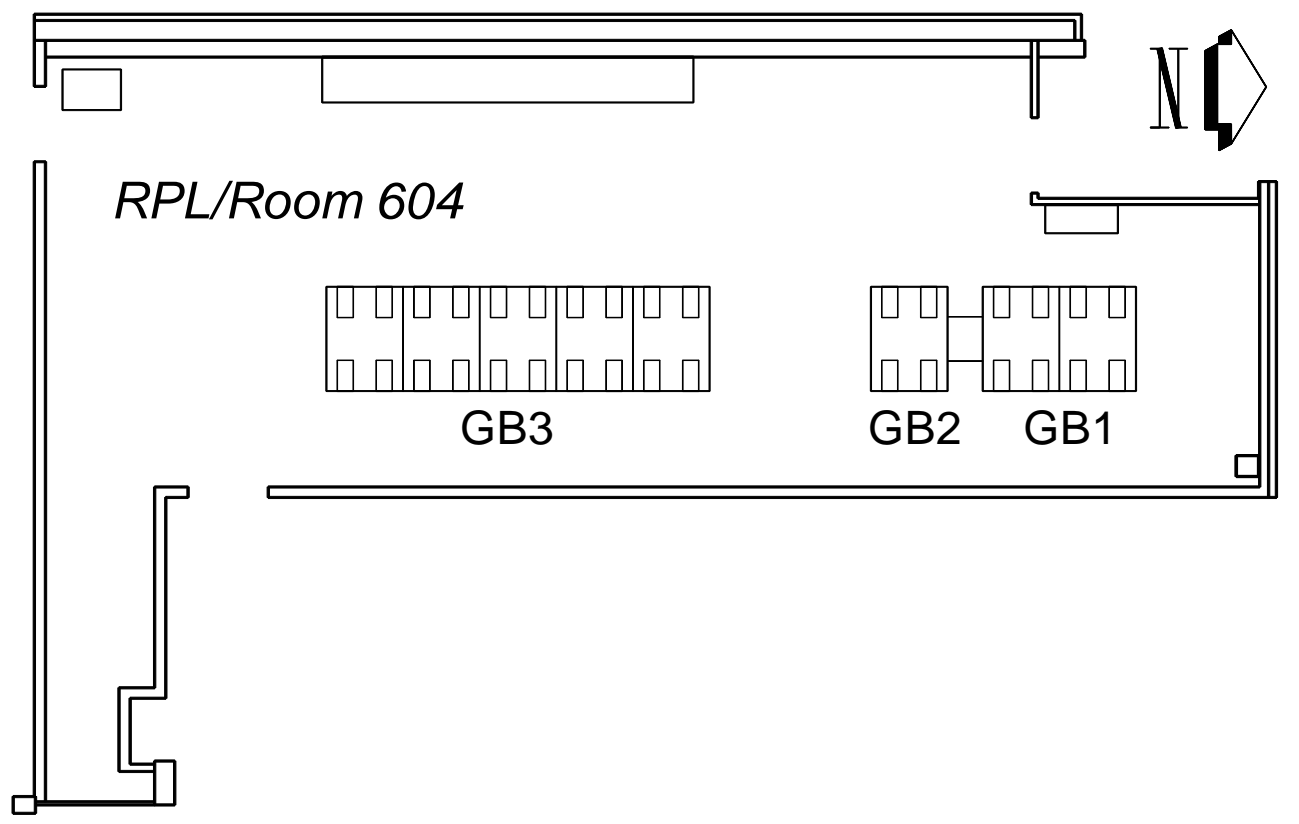

Figure 5.1. Layout of RPL/Room 604. GB denotes glovebox.

\subsection{Equipment Layouts}

Figure 5.2 and Figure 5.3 conceptually illustrate how the dissolution, ion-exchange, and oxalate precipitation operations would be located in Glovebox \#3 in RPL/Room 604. The dimensions for the various process vessels shown in the figures are based on a preliminary assessment of criticality risk, and 
are subject to change. Nevertheless, the figures provide a good idea of how the equipment might be configured within the glovebox. All tanks will be installed on the east side of Glovebox \#3, so that the west side of the glovebox can be devoted to performing the required operations. Where possible, tanks will be mounted one over the other to conserve footprint in the glovebox.

The receipt and dissolution operations will be conducted at the south end of Glovebox \#3 near the airlock. These include weighing, dissolving, and filtering operations. The clarified $\mathrm{Pu}$ solution will be collected into Tank 1a or $1 \mathrm{~b}$. The Pu solution will be transferred to Tank $2 \mathrm{a}$ or $2 \mathrm{~b}$ and chemically adjusted for feed to the anion exchange column, which is located toward the center of Glovebox \#3. The ion exchange effluent, including the $7 \mathrm{M} \mathrm{HNO}_{3}$ column wash solution will be collected into Tank $3 \mathrm{a}$ or $3 \mathrm{~b}$. Tanks 1 through 3 can be constructed from stainless steel because these are "upstream" of the purified $\mathrm{Pu}$ solution. Furthermore, it might be necessary to shield Tank 3 because of the gamma radiation produced by ${ }^{241} \mathrm{Am}$ in the ion exchange effluent. The purified Pu solution will be collected into Tank $4 \mathrm{a}$ or $4 \mathrm{~b}$. To avoid contamination of the purified $\mathrm{Pu}$ with metallic corrosion products, these tanks will be constructed from a rugged plastic material. The purified Pu solution will be transferred to Tank 5a or 5b and chemically adjusted for the oxalate precipitation step. Again, to avoid metallic contamination, Tanks 5a and $5 \mathrm{~b}$ will be constructed from plastic. The precipitation vessel and oxalate filtration apparatus will be located at the north end of Glovebox \#3. The filtrate from the oxalate precipitation step will be collected in stainless steel Tanks $6 \mathrm{a}$ or $6 \mathrm{~b}$.

The calcination furnace will be installed in Glovebox \#1. The furnace will be situated in a manner to allow most convenient access. Figure 3.4 illustrates some possible options for placement of the calcination furnace. Other than a balance, no special equipment is expected to be installed in Glovebox \#2 for the purposes of packaging the $\mathrm{PuO}_{2}$ materials, so a layout for Glovebox \#2 is not specified at this point. 


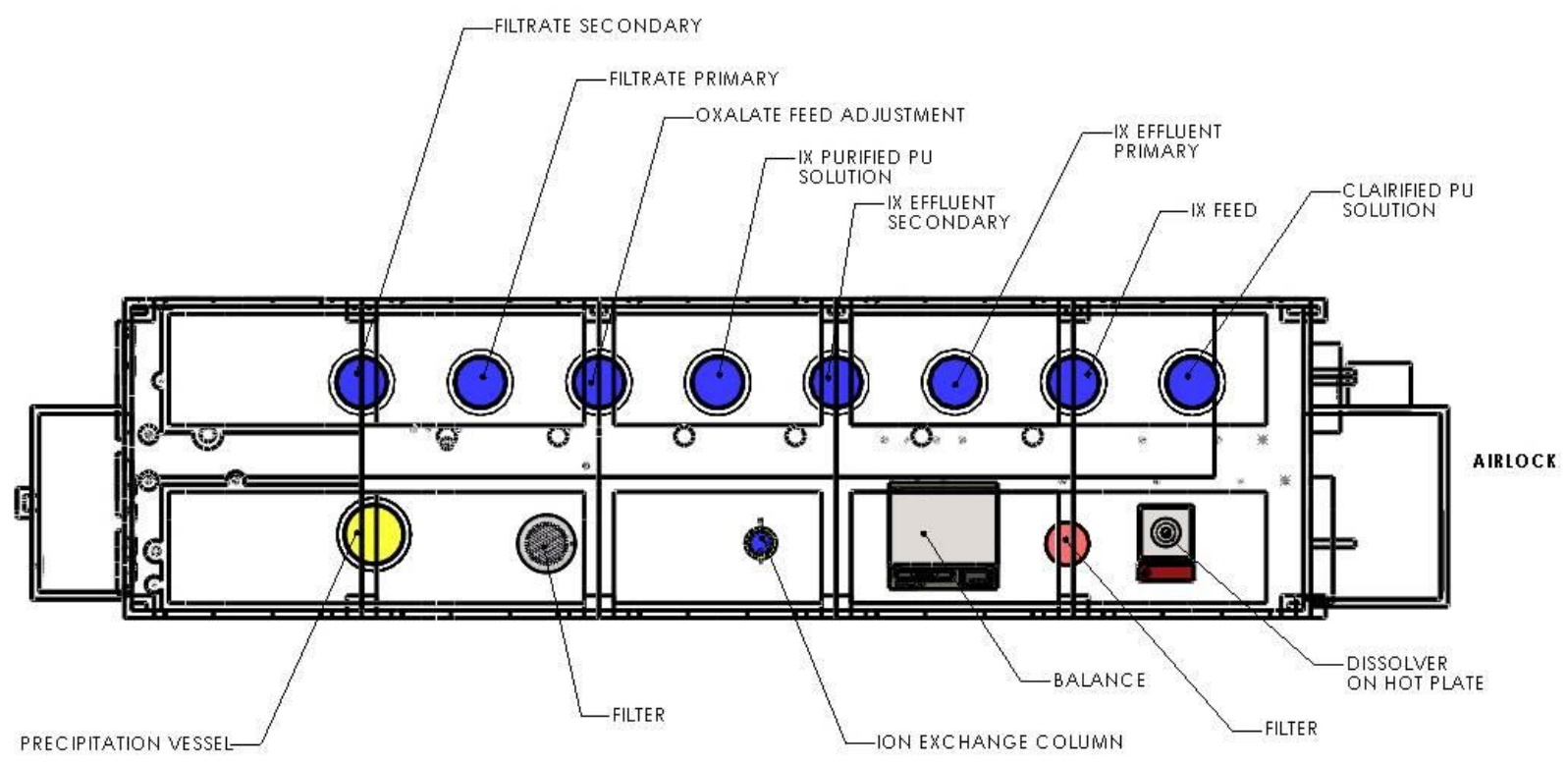

Figure 5.2. Conceptual Layout of Equipment in Glovebox \#3, (view from above). IX denotes ion exchange.

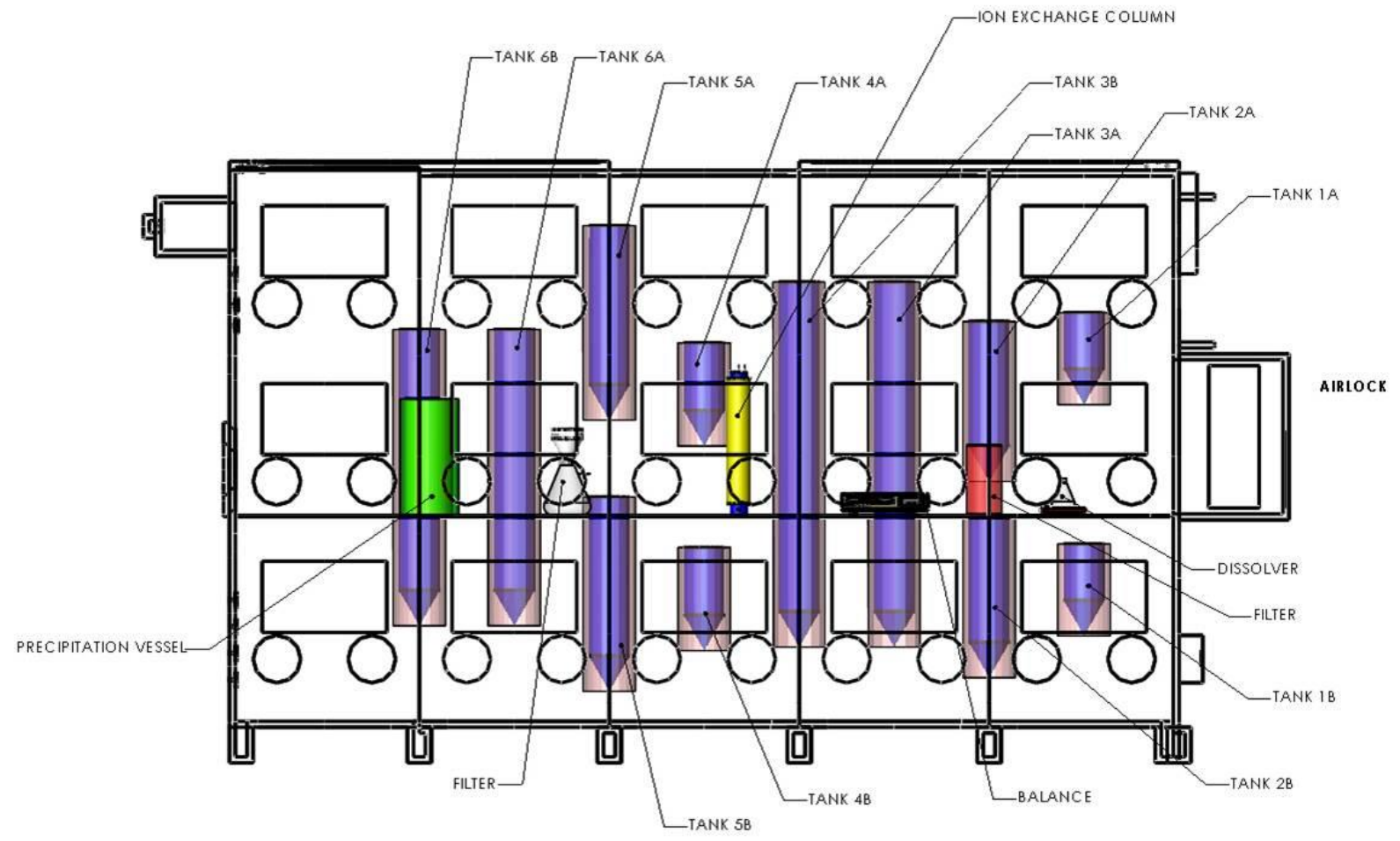

Figure 5.3. Conceptual Layout of Equipment in Glovebox \#3, (view from the west side of the box) 



\subsection{Material Inputs and Outputs}

This chapter provides an estimate of the flow of materials into and out of the P3U capability. It should be noted that a rigorous evaluation of the flowsheet has not been performed, and thus the values reported here should be viewed as indicative, not definitive.

\subsection{Dissolution}

Figure 6.1 illustrates the flows into and out of the dissolver section of the process. The primary inputs and outputs for the dissolution portion of the flowsheet are as follows.

Inputs:

Stream 1: $226 \mathrm{~g}$ of as-received $\mathrm{PuO}_{2}$

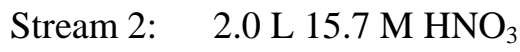

Stream 3: $\quad 15.6 \mathrm{~g} \mathrm{CaF}_{2}$

Outputs:

Stream 4: the clarified impure Pu solution, estimated to contain $513 \mathrm{~g} \mathrm{H}_{2} \mathrm{Pu}\left(\mathrm{NO}_{3}\right)_{6}, 1662 \mathrm{~g}$ $\mathrm{HNO}_{3}, 15.6 \mathrm{~g} \mathrm{CaF}_{2}$, and $892 \mathrm{~g} \mathrm{H}_{2} \mathrm{O}$.

The undissolved solids could be recycled back to the dissolver or disposed of. Because the amounts and identities of the undissolved solids are unknown, these materials are not accounted for in the mass flow.

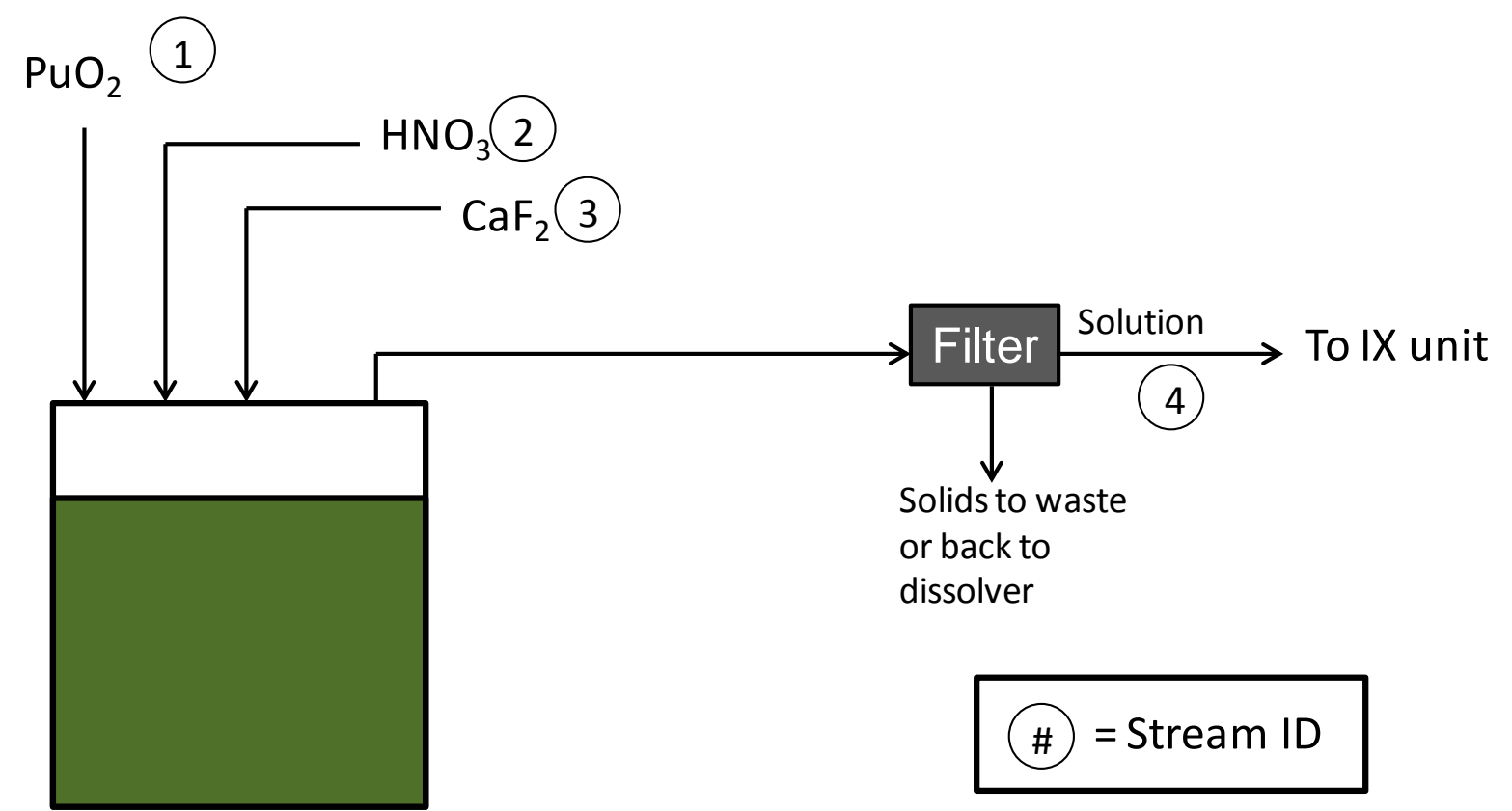

Figure 6.1. Material Flows into and out of the Dissolver Section. IX denotes ion exchange. 


\subsection{Ion Exchange}

The material flows into and out of the ion exchange section of the P3U process are shown in Figure 6.2. The primary inputs and outputs for the dissolution portion of the flowsheet are as follows.

Inputs:

Stream 4: as described above

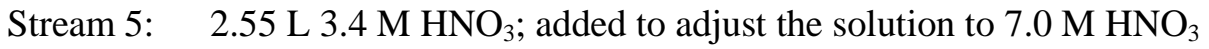

Stream 6: $\quad 0.25 \mathrm{~L} 1.6 \mathrm{M} \mathrm{Al}\left(\mathrm{NO}_{3}\right)_{3}$; added to complex $\mathrm{F}^{-}$ion (1 mole $\left.\mathrm{Al} / \mathrm{mole} \mathrm{F}\right)$

Stream 7: $\quad 0.2 \mathrm{~L} 30 \% \mathrm{H}_{2} \mathrm{O}_{2}$; added to adjust to $\mathrm{Pu}(\mathrm{IV})$

Stream 8: adjusted ion-exchange feed solution

Stream 9: $\quad$ 7.4 $\mathrm{L} \mathrm{M} \mathrm{HNO}_{3}$; column wash with 6 bed volumes

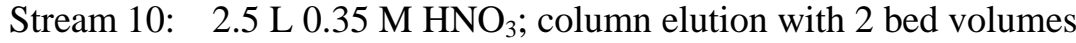

Outputs:

Stream 11: purified Pu solution; estimated to contain $513 \mathrm{~g} \mathrm{H}_{2} \mathrm{Pu}\left(\mathrm{NO}_{3}\right)_{6}, 55 \mathrm{~g} \mathrm{HNO}_{3}$, and $2,450 \mathrm{~g} \mathrm{H}_{2} \mathrm{O}$

Stream 12: effluent containing the impurities; estimated to contain $5490 \mathrm{~g} \mathrm{HNO}_{3}, 15.6 \mathrm{~g}$

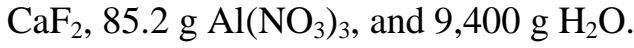




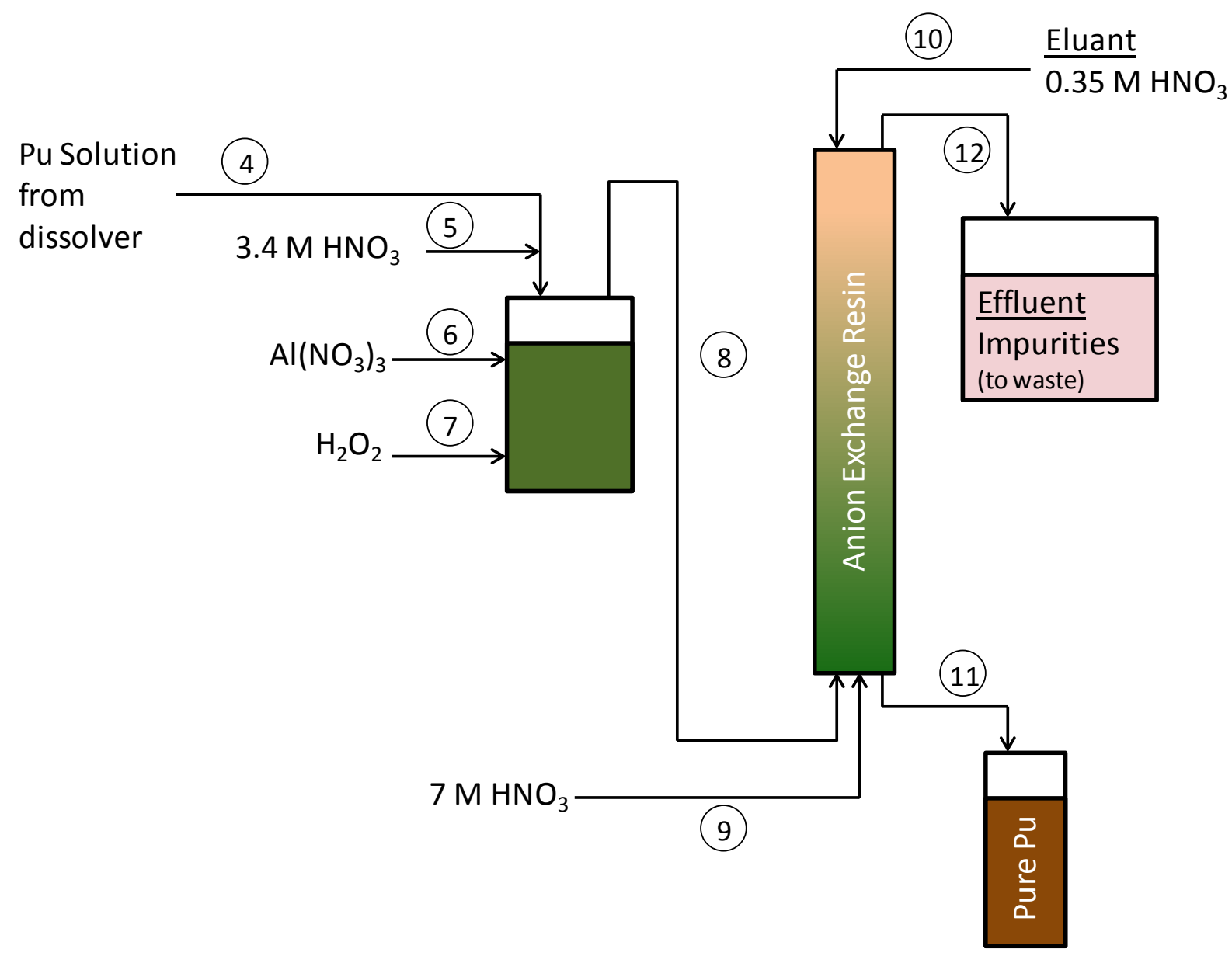

Figure 6.2. Material Flows into and out of the Ion Exchange Section

\subsection{Precipitation}

Figure 6.3 illustrates the material inputs and outputs from the precipitation section of the process. The primary inputs and outputs for the dissolution portion of the flowsheet are as follows.

\section{Inputs:}

Stream 11: as described above

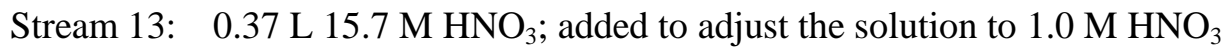

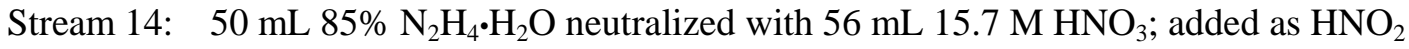
scavenger

Stream 15: $300 \mathrm{~g}$ ascorbic acid; added to adjust to $\mathrm{Pu}(\mathrm{III})$

Stream 16: $270 \mathrm{~g} \mathrm{H}_{2} \mathrm{C}_{2} \mathrm{O}_{4} \cdot 2 \mathrm{H}_{2} \mathrm{O}$

Stream 18: $\quad 0.7 \mathrm{~L} 0.2 \mathrm{M} \mathrm{HNO}_{3} / 0.1 \mathrm{M} \mathrm{H}_{2} \mathrm{C}_{2} \mathrm{O}_{4}$; oxalate product wash 


\section{Outputs:}

Stream 17: $385 \mathrm{~g} \mathrm{Pu}_{2}\left(\mathrm{C}_{2} \mathrm{O}_{4}\right)_{3} \cdot 10 \mathrm{H}_{2} \mathrm{O}$ product

Stream 19: filtrate and wash; estimated to contain $485 \mathrm{~g} \mathrm{HNO}_{3}, 28 \mathrm{~g} \mathrm{~N}_{2} \mathrm{H}_{4}, 300 \mathrm{~g}$ ascorbic acid (or oxidized product thereof), $86 \mathrm{~g} \mathrm{H}_{2} \mathrm{C}_{2} \mathrm{O}_{4}$, and 7,310 $\mathrm{g} \mathrm{H}_{2} \mathrm{O}$.

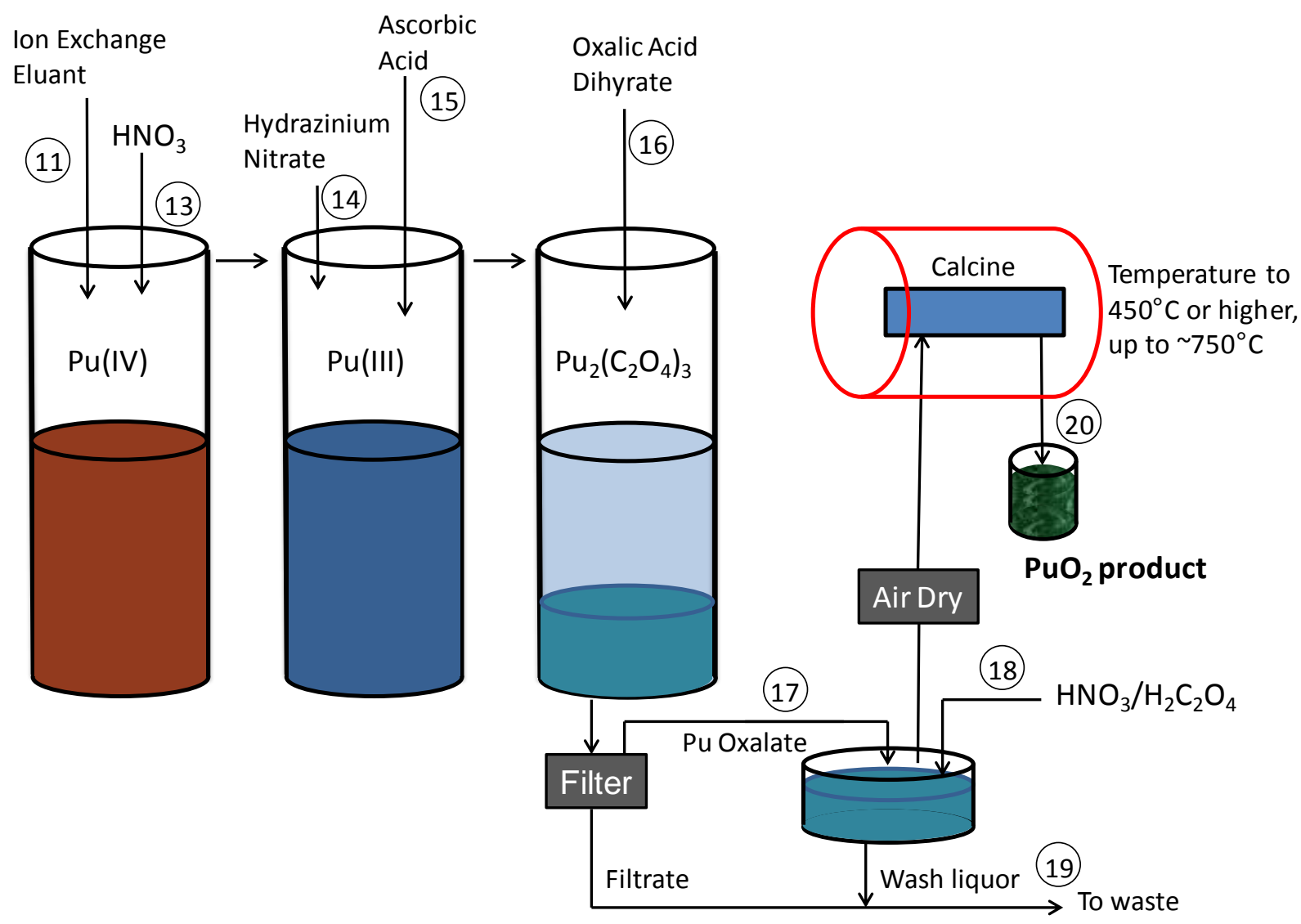

Figure 6.3. Material Flows into and out of the Precipitation and Calcination Sections

\subsection{Calcination}

Figure 6.3 also shows the material flow into and out of the calciner (excluding off-gas). The primary inputs and outputs for the dissolution portion of the flowsheet are as follows.

Inputs:

Stream 17: $385 \mathrm{~g} \mathrm{Pu}_{2}\left(\mathrm{C}_{2} \mathrm{O}_{4}\right)_{3} \cdot 10 \mathrm{H}_{2} \mathrm{O}$ product (after washing)

Outputs:

Stream 20: $226 \mathrm{~g} \mathrm{PuO}_{2}$ product (100\% recovery assumed). 


\subsection{References}

1. Bryan, S. A.; Levitskaia, T. G.; Casella, A. J.; Peterson, J. M.; Johnsen, A. M.; Lines, A. M.; Thomas, E. M.; Orton, C. R. Spectroscopic On-Line Monitoring for Process Control and Safeguarding of Radiochemical Streams. In Advanced separation techniques for nuclear fuel reprocessing and radioactive waste treatment; Nash, K. L.; Lumetta, G. J., Eds; Woodhead Publishing Ltd: Oxford, 2011; pp 95-119.

2. Bryan, S. A.; Levitskaia, T. G.; Casella, A. J.; Peterson, J. M.; Lines, A. M.; Verdugo, D. E.; Jordan, E. A. Spectroscopic On-Line Monitoring for Process Control and Safeguarding of Radiochemical Streams. 19th International Solvent Extraction Conference, Santiago, Chile, October 3-7, 2011; Gecamin Ltda: Santiago, Chile, 2011.

3. Bryan, S. A.; Levitskaia, T. G.; Johnsen, A. M.; Orton, C. R.; Peterson, J. M. Spectroscopic monitoring of spent nuclear fuel reprocessing streams: an evaluation of spent fuel solutions via Raman, visible, and near-infrared spectroscopy. Radiochim. Acta 2011, 99, 563-571.

4. Marsh, S. F.; Gallegos, T. D. Chemical Treatment of Plutonium with Hydrogen Peroxide Before Nitrate Anion Exchange Processing; LA-10907; Los Alamos National Laboratory: Los Alamos, NM, 1987.

5. Ryan, J. L. Purification of Plutonium Using Lewatit UMP-950 Ion Exchange Resin; Procedure 325PU-Purify-1; Pacific Northwest National Laboratory: Richland, WA, 1998.

6. Ryan, J. L.; Wheelwright, E. J. Recovery and Purificatino of Plutonium by Anion Exchange. Ind. Eng. Chem. 1959, 51 (1), 60-65.

7. Gilman, W. S. A Review of the Dissolution of Plutonium Oxide; MLM-1264; AEC Research and Development Report, Monsanto Research Corporation: Miamisburg, OH, 1965.

8. Barney, G. S. The Kinetics of Plutonium Oxide Dissolution in Nitric/Hydrofluoric Acid Mixtures. J. Inorg. Nucl. Chem. 1976, 39 (9), 1665-1669.

9. Kazanjian, A. R.; Stevens, J. R. Dissolution of Plutonium Oxide in Nitric Acid at High Hydrofluoric Acid Concentrations; RFP-3609; Rockwell International, Rocky Flats Plant: Golden, CO, 1984.

10. Martinez, B. T.; Roybal, J. D.; Valdez, J. A.; Bluhm, E. A.; Coriz, F. Dissolution Experiments for the Plutonium Oxide Polishing for MOX Fuel Fabrication; LA-UR-04-1689; Los Alamos National Laboratory: Los Alamos, NM, 2004.

11. WHC, U. Plutonium Oxide Production and Rework Facility, PUREX Technical Manual Addendum I; WHC-SP-0479; Westinghouse Hanford Company: Richland, WA, 1989.

12. Kyser, E. A. Plutonium Loading onto Reillex HPQ Anion Exchange Resin; WSRC-TR-2000-00372; Westinghouse Savannah River Company: Aiken, SC, 2000.

13. Kyser, E. A. Neptunium Valence Chemistry in Anion Exchange Processing; WSRC-TR-2003-00111; Westinghouse Savannah River Company: Aiken, SC, 2003. 
14. Kyser, E. A.; King, W. D.; O'Rourke, P. E. Plutonium Loading Capacity of Reillex HPQ Anion Exchange Column - AFS-2 Plutonium Flowsheet for MOX; SRNL-STI-2012-00387; Savannah River National Laboratory: Aiken, SC, 2012.

15. Barr, M. A.; Jarvinen, G. D.; Stark, P. C.; Chamberlin, R. M.; Bartsch, R. A.; Zhang, Z. Y.; Zhao, W. Americium Separations from High-Salt Solutions Using Anion-Exchange. Sep. Sci. Technol. 2001, 36, 2609-2622.

16. Steimke, J. L.; Williams, M. R.; Steeper, T. J.; Leishear, R. A. Nitrate Conversion of HB-Line Reillex HPQ Resin; SRNL-STI-2012-00160; Savannah River National Laboratory: Aiken, SC, 2012.

17. Laurinat, J. E.; Crooks III, W. J.; Kyser III, E. A. Impact of the Low-Temperature Reactivity of Reillex HPQ on Actinide Processing. Solvent Extr. Ion Exch. 2002, 20, 525-542.

18. Alwin, J. L.; Coriz, F.; Danis, J. A.; Bluhm, B. K.; Wayne, D. W.; Gray, D. W.; Ramsey, K. B.; Costa, D. A.; Bluhm, E. A.; Nixon, A. E.; Garcia, D. J.; Roybal, J. D.; Saha, M. T.; Valdez, J. A.; Martinez, D.; Martinez, J. R.; Martinez, C. M.; Martinez, Y. A.; Martinez, C. M. Plutonium oxide polishing for MOX fuel fabrication. J. Alloys Compd. 2007, 444-445, 565-568.

19. Porter, J. A.; Symonds, J., A. E. Precipitation of Plutonium(III) Oxalate and Calcination to Plutonium Dioxide; DP-981; EI du Pont de Nemours and Company, Savannah River Laboratory: Aiken, SC, 1965.

20. Greinetz, R. M.; Neal, D. H. Plutonium(III) Oxalate Precipitation and Calcination Process for Plutonium Nitrate to Oxide Conversion; RFP-2603; Rockwell International Energy Systems Group: Golden, CO, 1980.

21. Hoyt, R. C.; Bouse, D. G.; Ludowise, J. D. Interim Report on Plutonium Oxalate Precipitation Work, 1/15/82 to 3/15/83; SD-CP-TI-014; Rockwell Hanford Operations: Richland, WA, 1983.

22. Silver, G. Plutonium Oxalates as Sources of Plutonium Dioxide; UR-10-02596; Los Alamos National Laboratory: Los Alamos, NM, 2010.

23. Nissen, D. A. The Thermal Decomposition of Plutonium(IV) Oxalate Decahydrate. J. Therm. Anal. 1980, 18, 99-109.

24. Myers, M. N. Thermal Decomposition of Plutonium (IV) Oxalate and Hydrofluorination of Plutonium (IV) Oxalate and Oxide; HW-45128; General Electric Co., Hanford Atomic Products Operation: Richland, WA, 1956.

25. Wick, O. J. Plutonium Handbook: A Guide to the Technology. Gordon and Breach: New York, 1967; Vol. II.

26. Rao, G. S.; Subramaniam, M. S.; Welch, G. A. Thermal Decomposition of Plutonium Oxalates. J. Inorg. Nucl. Chem. 1963, 25, 1293-1300.

27. Thompson, M. A. Plutonium Processing Materials Data Book; CRDL-950612-002; Dow Chemical U.S.A., Rocky Flats Division: Golden, CO, 1972.

28. Ryan, J. L.; Bryan, G. H.; Burt, M. C.; Castanzo, D. Preparation of Standards for and Determination of Free Acid in Concentrated Plutonium-Uranium Solutions. Anal. Chem. 1985, 57, 1423-1427. 


\section{Distribution}

No. of

Copies

\# Name

Organization

Address

City, State and ZIP Code

\# Organization

Address

City, State and ZIP Code

Name

Name

Name

Name

Name (\#)

\# Name

Organization

Address

City, State and ZIP Code
No. of

Copies

\# Foreign Distribution

\# Name

Organization

Address

Address line 2

COUNTRY

\# Local Distribution

Pacific Northwest National Laboratory

Name

Name

Mailstop

Mailstop

Name

Mailstop

Name

Mailstop

Name

Distr.1 




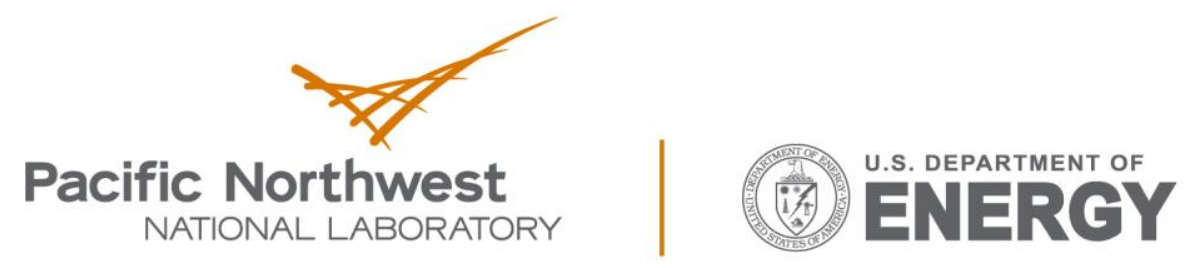

Proudly Operated by Battelle Since 1965

902 Battelle Boulevard

P.O. Box 999

Richland, WA 99352

1-888-375-PNNL (7665)

www.pnnl.gov 